$x_{x}^{9298(1)}$

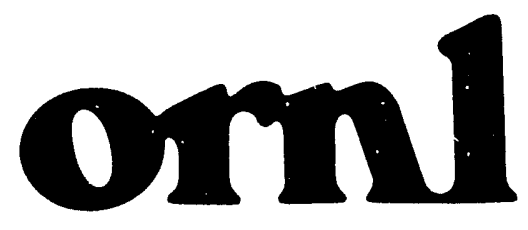

OAK RIDGE

NATIONAL

LABORATORY

MARTIN MARTETRA
ORNL/CON-342

EVALUATION OF THE COMPUTERIZED UTILITIES ENERGY MONITORING AND CONTROL SYSTEM INSTALLED AT THE U.S. MILITARY COMMUNITY AT GOEPPINGEN, GERMANY

Steven L. Purucker

Michael B. Gettings

November 1991 
This report has reproduced directly from the best available copy.

Available to DOE and DOE contractors from the Office of Scientific and Technical Information, P.O. Box 62. Oak Ridge, TN 37831; prices availablo from (815) 576.8401, FTS 626-8401.

Available to the public from the National Technical Information Service, U.S. Department of Commerce, 5285 Port Royal Rd., Springfield, VA 22161.

This repor was prepared as an account of work sponsored by an agency of the United States Government. Neither the United States Government nor any agency thereot. nor any of their employees, makes any warranty, express or implied, or assumes any legal liability or responsibility for the accuracy, completeness, or usefulness of any information, apparatus, product, or process disclosed, or represents that its use would not infringe privately owned rights. Reterence herein to any spectic commercial product, process, or service by trade name. trademark, manutaciurer, or otherwise, does not necessarily constilute or imply its endorsement. recommerdation. or lavoring by the United States Government or any agency thereot. The views and opinions of authors expressed herein do not neressarily state or reflect those of the United States Government or any agency thergot. 


\section{EVALUATION OF THE COMPUTERIZED UTILITIES ENERGY MONITORING AND CONTROL SYSTEM INSTALLED AT THE U.S. MILITARY COMMUNITY AT GOEPPINGEN, GERMANY}

by

Steven L. Purucker

Michael B. Gettings

Energy Division

Oak Ridge National Laboratory

November 18, 1991

PREPARED BY THE OAK RIDGE NATIONAL LABORATORY

Oak Ridge, Tennessee 37831-6285 managed by

MARTIN MARIETTA.ENERGY SYSTEMS, INC. for the

U.S. DEPARTMENT OF ENERGY under contract DE-AC05-84OR21400 
TABLE OF CONTENTS

LIST OF FIGURES $\ldots \ldots \ldots \ldots \ldots \ldots \ldots \ldots \ldots \ldots \ldots \ldots \ldots \ldots \ldots$

LIST OF TABLES $\ldots \ldots \ldots \ldots \ldots \ldots \ldots \ldots \ldots \ldots \ldots \ldots \ldots \ldots \ldots \ldots \ldots \ldots \ldots \ldots$

EXECUTIVE SUMMARY $\ldots \ldots \ldots \ldots \ldots \ldots \ldots \ldots \ldots \ldots \ldots \ldots \ldots \ldots \ldots \ldots$

ABSTRACT $\ldots \ldots \ldots \ldots \ldots \ldots \ldots \ldots \ldots \ldots \ldots \ldots \ldots \ldots \ldots \ldots \ldots \ldots \ldots \ldots \ldots \ldots$

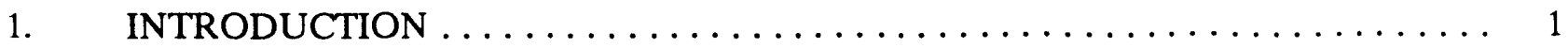

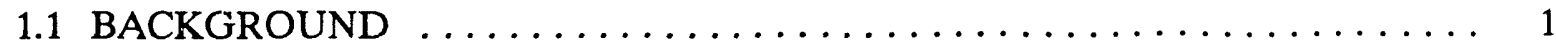

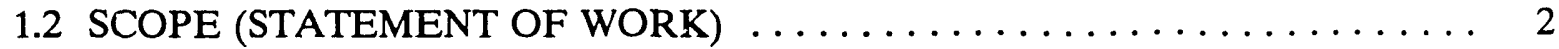

2. PROJECT APPROVAL DOCUMENTATION $\ldots \ldots \ldots \ldots \ldots \ldots \ldots \ldots \ldots$

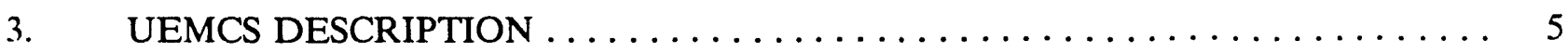

4. ASSESSMENT OF SITE AND PHYSICAL CONDITIONS $\ldots \ldots \ldots \ldots \ldots \ldots \ldots$

4.1 GOEPPINGEN-COOKE BARRACKS AND FAMILY HOUSING $\ldots \ldots \ldots 11$

4.2 SCHWAEBISCH GMUEND, HARDT KASERNE, FAMILY HOUSING, AND

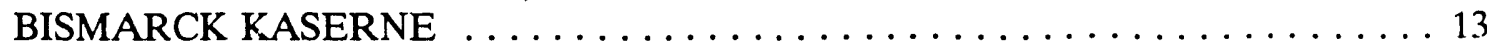

5. ANALYSIS OF ENERGY CONSUMPTION AND COSTS $\ldots \ldots \ldots \ldots \ldots \ldots$

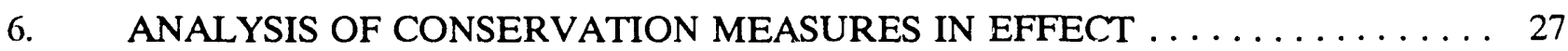

6.1 ENERGY SAVINGS ATTRIBUTED TO EACH MEASURE . . . . . . . . . . . 29

6.2 SUMMARY OF UEMCS ENERGY SAVINGS AND COST SAVINGS $\ldots \ldots \quad 32$

6.3 COMPARISON OF PREDICTED UEMCS SAVINGS TO HISTORICAL

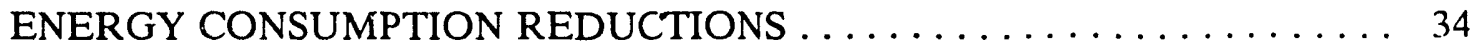

6.4 GENERAL ASSESSMENT OF BENEFITS $\ldots \ldots \ldots \ldots \ldots \ldots \ldots \ldots \ldots \ldots$

7. ANALYSIS OF CONSERVATION MEASURES WHICH COULD BE

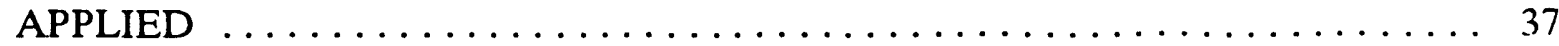

8. CONCLUSIONS $\ldots \ldots \ldots \ldots \ldots \ldots \ldots \ldots \ldots \ldots \ldots \ldots \ldots \ldots \ldots \ldots \ldots$

9. RECOMMENDATIONS $\ldots \ldots \ldots \ldots \ldots \ldots \ldots \ldots \ldots \ldots \ldots \ldots \ldots \ldots \ldots$

REFERENCES $\ldots \ldots \ldots \ldots \ldots \ldots \ldots \ldots \ldots \ldots \ldots \ldots \ldots \ldots \ldots \ldots \ldots \ldots \ldots$

APPENDICES $\ldots \ldots \ldots \ldots \ldots \ldots \ldots \ldots \ldots \ldots \ldots \ldots \ldots \ldots \ldots \ldots \ldots \ldots$ 


\section{LIST OF FIGURES}

Figure 1. Hardware architecture of UEMCS $\ldots \ldots \ldots \ldots \ldots \ldots \ldots \ldots \ldots$

Figure 2. Schematic of the Goeppingen district heat system $\ldots \ldots \ldots \ldots \ldots$

Figure 3 . Total community heat energy consumption $\ldots \ldots \ldots \ldots \ldots \ldots \ldots \ldots$

Figure 4. Goeppingen's heat energy consumption $\ldots \ldots \ldots \ldots \ldots \ldots \ldots \ldots \ldots \ldots$

Figure 5. Schwaebisch Gmuend's heat energy consumption $\ldots \ldots \ldots \ldots \ldots \ldots \ldots \ldots$

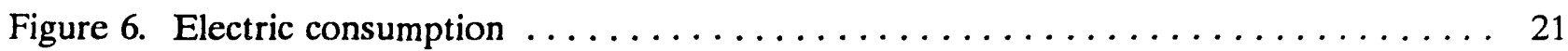

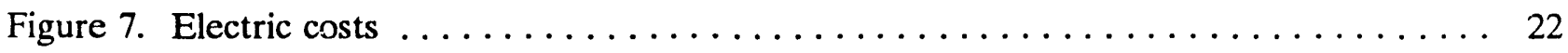

Figure 8. Goeppingen's energy expenditures $\ldots \ldots \ldots \ldots \ldots \ldots \ldots \ldots \ldots \ldots \ldots \ldots$

Figure 9. Schwaebisch Gmuend's energy expenditures $\ldots \ldots \ldots \ldots \ldots \ldots \ldots \ldots$

Figure 10. Total community energy expenditures $\ldots \ldots \ldots \ldots \ldots \ldots \ldots \ldots \ldots \ldots$ 


\section{LIST OF TABLES}

Table 1. Goeppingen electrical energy and demand charges $(1000 \mathrm{DM}) \ldots \ldots \ldots$

Table 2. Schwaebisch Gmuend electrical energy and demand charges (1000 DM) . . . . 23

Table 3. Conservation applications in effect at Goeppingen $\ldots \ldots \ldots \ldots \ldots \ldots \ldots$

Table 4. Estimated UEMCS Energy and Cost Savings $\ldots \ldots \ldots \ldots \ldots \ldots \ldots \ldots \ldots$ 


\section{EXECUTIVE SUMMARY}

Under the provisions of Interagency Agreement DOE No. 1938-B090-A1 between the U.S. Department of Energy (DOE) and the United States Army in Europe (USAREUR), the Oak Ridge National Laboratory (ORNL) was selected to evaluate the overall effectiveness and energy efficiency of Utilities and Energy Monitoring and Control Systems (UEMCSs) at four U.S. Army installations in Germany, located at Heidelberg, Goeppingen, Pirmasens, and Baumholder. This document reports on the evaluation of the UEMCS installed at the U.S. Military Community Activity at Goeppingen. This evaluation relied upon existing data and information and did not involve the installation of metering and instrumentation for the purpose of measuring installation energy use.

The Goeppingen military community includes the facilities of Cooke Barracks and Goeppingen Hohenstaufester and Buergerhoelzle Family Housing, collectively referred to as Goeppingen. Additional facilities are located near Schwaebisch Gmuend, including Hardt and Bismarck Kasernes and Family Housing at Schwaebisch Gmuend. This area is collectively referred to as Schwaebisch Gmuend.

Goeppingen's UEMCS was installed during 1986 and 1987 as part of the conversion from oiland coal-boiler-produced steam heat to city-owned warm-water district heat for a majority of the facility. No separate documentation exists for installation of the UEMCS system. All cost and savings estimates submitted for project approval were for the UEMCS/district heat conversion combination. Although construction during this period included installation of district heat anci UEMCS systems at both Goeppingen and Schwaebisch Gmuend, most of the information obtained was for the Goeppingen system, which is the focus of this report. The system at Schwaebisch Gmuend has no central computer associated with its UEMCS, but it requires only a dedicated telephone line to connect it with Goeppingen's system, thereby integrating the two UEMCSs.

The project at Goeppingen was funded under two separate authorizations (DD Form 1391A) for which the latest revisions are both dated December 11, 1985. Appendix B provides summary data of these two authorizations taken from both the original and the revised DD Form 1391A documents. The total cost was $\$ 5,415,530$. District heat was installed in 75 buildings, 20 of which were family housing. The project installed 12 UEMCS substations which are monitored and controlled by the Landis \& Gyr Visonik 4000 EMCS system using a Digital Equipment Corporation PDP 11/73 computer. (Detailed computer specifications could not be located.) Additional peripheral equipment 
includes both a color monitor and a monochrome monitor, keyboard console, and hardwire communication lines. The project justification anticipated an energy reduction of $30 \%$ for district heating as well as a $15 \%$ reduction in water usage.

The UEMCS is a supervisory control system with distributed intelligence in local process controllers. The local controllers perform the following basic functions: (1) adjust building districtheat temperature based on outside air temperature, (2) maintain domestic hot water at a constant temperature, (3) adjust district-heat water pump speeds to maintain a constant flow of warm water through each register, and (4) maintain desired room temperatures in buildings that require ventilation.

The UEMCS makes operational adjustments which require the coordination of all the buildings. Supervisory control at Goeppingen includes the following central functions: (1) $5^{\circ} \mathrm{C}$ night setback, (2) a "quick-heat" recovery from night setback, (3) seasonal shutdown of heating pumps from May through October, (4) switchover to higher-capacity pumps for greater heating capacity, and (5) the option to shut off domestic hot water circulation pumps during nighttime hours (available, but not currently used).

In general, all facilities under UEMCS control that were visited were clean and well maintained. With the installation of district heat and hot water heating, the operating environment for the UEMCS equipment has been made less severe. The electrical system is not currently connected to the UEMCS, but the substations are relatively new and contain much of the equipment needed for the connection. The transformers are fixed-tap transformers eliminating voltage control by the UEMCS as a conservation measure.

Water consumption at Goeppingen is comparatively high as well as expensive. Directorate of Engineering and Housing personnel were not aware of any reasons why water consumption is so high, indicating that the UEMCS may be used for monitoring consumption and identifying consumers.

Buildings at Goeppingen generally have 12 in. of insulation in the attic area and eaves, but no attempt has been made to retrofit walls with insulation. The windows in most buildings are double insulated and very tight. However, windows are often open, even during the winter, io provide adequate ventilation. With warm water radiators supplying the majority of heat, no other means of ventilation is available.

Since metered data associated with UEMCS energy conservation measures were not available, estimates of measure savings are provided from engineering estimates based on avai'able data, 
experience and data obtained in a previous study, and computational methods supported by the Army Corps of Engineers, in Huntsville, Alabama.

The thermal energy consumption of the total community and of Goeppingen alone has decreased by $128 \mathrm{kMBtu}$ and $81 \mathrm{kMBtu}$ ( $36 \%$ and $41 \%$ ), respectively, over the period during which the UEMCS and district heating were installed. On the other hand, electrical consumption has increased over the same period by about $22 \mathrm{kMBtu}$ and $13 \mathrm{kMBtu}$ (each 38\%) respectively. However, the total MBtu consumed (thermal plus electrical) has decreased since the UEMCS/district heating system was installed. The total deutsche mark (DM) expended on energy has increased since the installation because of the utility charge related to repayment for the district-heating plant construction and to a minimum consumption charge. Total community electrical demand charges in 1989 represented 53\% of the total electrical charge, indicating substantial savings potential for UEMCS-imposed demand limiting.

Estimated heating savings attributed directly to the UEMCS at Goeppingen represent approximately $9 \%$ of the annual heating energy consumption, compared with the $27 \%$ reported for the Heidelberg UEMCS. The majority of this difference stems from Heidelberg's reported savings credited to nighttime shutoff of the domestic hot water (DHW) circulation pumps (not performed at Goeppingen) and the higher percent savings assigned to night setback at Heidelberg.

Electrical savings credited to the UEMCS are less than in the previously studied Heidelberg system due mainly to (1) the use of photocells, instead of the UEMCS, to control exterior lighting, (2) smaller equipment sizes and quantities, (3) no UEMCS control over space heaters, airconditioners, or vending machines, and (4) no shutoff of DHW generators overnight.

The following additional conclusions result from the examination of individual measures as well as from observations and data obtained while visiting the site. Implementation costs for the recommendations could not be determined for this report. Herever, the community's facility engineering department should be able to estimate these costs fairly easily.

- The conversion to district heat from fossil-fueled hoilers at the Goeppingen facilities and Hardt Kaserne at Schwaebisch Gmuend has produced the majority of energy savings.

- The day/night setback measure saves the majority of energy resulting from UEMCS implementation, approximately $7000 \mathrm{MBtu} / \mathrm{year}$. The summer/winter switchover program has the potential to save about $1700 \mathrm{MBtu} / \mathrm{year}$. Other UEMCS measures combined save less than $1300 \mathrm{MBtu} / \mathrm{year}$. 
- The total estimated UEMCS-related savings at the Goeppingen facilities is $10 \mathrm{kMBtu} / \mathrm{year}$ (DM 400,000/year).

Recommendations based on the on-site observations, data analyses, and potential energy savings calculations include the following:

- Connect tine electrical system at Goeppingen to the UEMCS and implement demand limiting. Potential savings of $\mathrm{kDM} 106 /$ year are estimated.

- Integrate the UEMCS systems at Goeppingen and Schwaebisch Gmuend using available phone lines.

- Install additional capacitors in the electrical system to improve power factor control at Cooke Barracks, Bismarck Kaserne, and Schwaebisch Gmuend family housing. Potential savings of kDM 155/yea“- are possible.

- Use the UEMCS to monitor water consumption and identify leaks. Investigate the major water users, especially at Goeppingen, in an attempt to determine if any conservation measures might be applicable. Examine Heidelberg's single-point water-leak detection method to ascertain its applicability at Goeppingen. Potential savings are kDM 37/year.

- Consider expanding the use of radiant heat to appropriate buildings.

- If the computer response time needs to be improved as more equipment is added to the UEMCS, consider expanding the computer's main memory.

- Continue to study and implement existing UEMCS hardware and software capabilities in the areas of maintenance management, data analysis, and energy trend and profile generation.

- Expand UEMCS monitoring capabilities to allow determination of energy consumption in individual buildings or complexes.

- Support additional examination of the application and assumptions regarding the night shutoff of DHW circulation pumps to provide resolution of savings estimates differences.

The following two recommendations apply generally to USAREUR's implementation of UEMCSs: - Examine potential me thods that individual installation UEMCS operators may use to evaluate energy savings resulting from UEMCS programs and other energy conservation measures. Support additional studies to produce USAREUR-wide consistent recommendations on system evaluation. The work already accomplished at Heidelberg and that available through previous Army publications provides an excellent starting point for such a study.

- Explore additional means of communicating successes, lessons learned, and potential problems among USAREUR UEMCS operators, allowing the experiences of each to benefit all. 


\begin{abstract}
Under the provisions of an Interagency Agreement between the U.S. Army and the Department of Energy, Martin Marietta Energy Systems, Inc., through the Oak Ridge National Laboratory, is evaluating the Utilities and Energy Monitoring and Control System (U:MCS) installed at the U.S. Military Community Activity at Goeppingen, Germany. This evaluation relies on cxamination of existing data and information to determine the effectiveness of the UEMCS. The Goeppingen UEMCS is an integral part of a combined UEMCS/district heating system which includes the UEMCS at Schwaebisch Gmuend, Germany. The system was installed during 1985 and 1986. The UEMCS at Goeppinge:: and Schwaebisch Gmuend are both weli designed, implemented, and maintained. The UEMCS is operated in a supervisory mode with distributed intelligence in local controllers. At present, the UEMCS at Schwaebisch Gmuend does not have a central computer, but requires only a dedicated phone line to couple with the one at Goeppingen.

Though the conversion to district heat has produced the majority of energy savings, the UEMCS day/night setback program also contributes substantially, with additional savings from start/stop programs, such as seasonal switchover, and various temperature control programs. Further opportunities for savings exist in increasing monitoring and control of water usage and connecting the community's electrical network to the UEMCS, permitting demand limiting and increased power factor control.
\end{abstract}




\section{INTRODUCTION}

\subsection{BACKGROUND}

Under the provisions of Interagency Agreement DOE No. 1938-B090-A1 between the U.S. Department of Energy (DOE) and the United States Army in Europe (USAREUR), Martin Marietta Energy Systems, Inc. (MMES) is providing research and development support and technical assistance in the areas of computer science, information engineering, energy studies, engineering, and systems development. One of the initial projects authorized under this interagency agreement calls for the evaluation of Utilities and Energy Monitoring and Control Systems (UEMCSs) installed at selected U.S. Army installations in Europe. Plans are currently under way to evaluate the overall performance and energy efficiency of UEMCSs installed at U.S. Army installations in Heidelberg, Goeppingen, Pirmasens, and Baumholder, Germany. This report presents the resu'ts of an evaluation of the UEMCS installed at U.S. Military Community Activity (USMCA) in Goeppingen, Germany, which is operated by the Directorate of Engineering and Housing (DEH), Utilities Division.

The military construction program of the Department of Defense initiated the Energy Conservation Investment Program (ECIP) in. FY 1976. ECIP was designed to make existing defense facilities and buildings more energy efficient and to simuitaneously reduce the cost of installation and operations. A specified goal of this program was to implement cost-effective energy conservation retrofit projects in existing defense facilities and buildings to reduce overall energy consumption in 10 years by $12 \%$. This report supports this effort by evaluating energy conservation cost effectiveness and identifying conservation opportunities. 


\subsection{SCOPE (STATEMENT OF WORK)}

The Oak Ridge National Laboratory (ORNL) was selected by Headquarters, USAREUR, Facilities Engineering Division, Utilities and Energy Branch in Heidelberg to evaluate the overall effectiveness and energy efficiency of UEMCSs at four U.S. Army installations in Germany. This report documents the evaluation: of the UEMCS instailed at the USMCA in Goeppingen. This evaluation relied upon existing data and information and did not involve the installation of metering and instrumentation for the purpose of measuring installation energy use.

ORNL's statement of work divides this assignment into two phases: Phase I-26th Support Group at Heidziberg, and Phase II-Greppingen, Pirmasens, and Baumholder. The Phase I effort is the subject of the report Evaluation of the Computerized Utilities Monitor and Control System Installed at the U.S. Army, Europe, 26th Support Group at Heidelberg, Germany (Broders and McConnell 1991). The Heidelberg facility is the most advanced UEMCS in Germany. In Phase I, a thorough analysis of Heidelberg's UEMCS was performed, examining performance data and other project documentation, and then, using engineering analysis and data extrapolation, estimating the impact of each operations and maintenance (O\&M) and conservation-related application.

As proposed in the Statement of Work, the thrust of Phase iI was to be threefold. First, existing energy conservation applications were to be identified and quantified using engineering analysis and data evaluation. Second, the applicability of UEMCS functions at Heidelberg to other Military Commands (MILCOMs) was to be determined. Third, potential savings of new functions were to be quantified using engineering judgement based on site conditions. The site visit, analysis, and report was ' $\mathrm{O}$ focus on making specific recommendations to improve UEMCS effectiveness. 


\section{PROJECT APPROVAL DOCUMENTATION}

This section briefly summarizes the documentation submitted for Goeppingen's UEMCS project approva:. The project approved was the district heating system of which the UEMCS is an element, so the justification focuses on the benefit of installing district heat (which includes the UEMCS). There is not a separate justification for the UEMCS. Project scope, timing, and cost are the primary areas of interest in this summary.

Prior to the installation of district heat in 1986 and 1987, heat was supplied primarily by coaland oil-fired boilers that fed steam heating systemis. These units were expensive to operate and were in poor condition, requiring excessive maintenance.

The project at Goeppingen's Cooke Barracks, GE13X, was funded under two separate authorizations (DD Form 1391A), both dated December 11, 1985. Appendix B provides summary data for these two projects taken from the original and revised DD Form 1391A documents. The total cost was $\$ 5,4,15,530$, of which approximately $20 \%$ was for family housing. District heat was installed in 75 buildings, 20 of which were family housing. The quantities of equipment installed are as follows:

206 pumps,

- 173 mixing valves,

- 705 radiators with thermostats,

- 81 domestic hot water generators,

- 122 manifolds,

- 6533 linear feet of long distance pipes,

- 12 EMCS substations, and

- 455 thermostats.

Some of the quantities itemized above were used in the analysis of conservation measures (Sect. 6). 
Project justification anticipated an energy reduction of $30 \%$ for district heating as well as a $15 \%$ reduction in water usage. 


\section{UEMCS DESCRIPTION}

This section describes the UEMCS, itemizing the number of points controlled, the iype of equipment monitored and controlled, the computer hardware and software, and the communication and control system. The district heat system is also described.

The UEMCS was installed during 1986 and 1987. The UEMCS system described ir this report monitors and controls district heat at Goeppingen's Cooke Barracks where the control computer is located. Although UEMCS facilities have also been installed at Schwaebisch Gmuend, they are not connected to the computer because a telephone line is not available from Schwaebisch Gmuend to Goeppingen (originally the computer was located at Schwaebisch Gmuend; it monitored and controlled district heat there). Once the telephone line is made available, district heat at Schwaebisch Gmuend can be integrated into the UEMCS.

The UEMCS covers the facilities at Goeppingen, which include: Cooke Barracks, Family Housing at Goeppingen Hohenstaufester, and Family Housing at Goeppingen Buergerhoelzle. This area is referred to collectively as Goeppingen or GE13X.

The UEMCS has the potential to cover the facilities at Schwaebisch Gmuend, which include: Hardt Kaserne, Family Housing at Schwaebisch Gmuend, and Bismarck Kaserne. This area is referred to collectively as Schwaebisch Gmuend. These facilities are also known as the Hardt Kaserne GE33R and Family Housing Area GE76B. The Bismarck Kaserne is still heated by lowpressure steam. The steam is generated by burning oil.

The UEMCS is monitored and controlled through Landis \& Gyr Visonik 4000 equipment. The computer is a Digital Equipment Corporation PDP $11 / 73$ computer. Control is performed both locally and centrally. Local controls are installed in individual buildings. In some instances one local controller controls heating for several buildings. One of the guiding principles used in the design of 
the heating control system was to give control responsibility to the local controllers wherever possible. This creates a fail-safe design so that local heating does not depend on the operability of the computer system. Local controllers perform the following basic functions:

(1) Adjust building district-heat temperature based on outside air temperature.

(2) Maintain domestic hot water (DHW) at a constant temperature.

(3) Adjust district-heat water-pump speeds to maintain a constant flow of warm water through each register and assure even heating in each room of a building.

(4) Maintain desired room temperatures in buildings that require ventilation by adjusting local flow controls to preheat incoming air in concert with other heating controllers.

Local controllers do what they do best: make small and perhaps frequent operational adjustments to the heating systems in the buildings they control. The "field of vision" for the local controller is the immediate building.

The supervisory portion of the UEMCS has a broader "field of vision." It can "see" the entire heating system. The UEMCS makes operational adjustments that require the coordination of all the buildings. Supervisory control at Goeppingen includes the following central functions:

(1) Night setback. The UEMCS gives a signal to the local controller to lower the district-heat secondary hot-water temperature by $5^{\circ} \mathrm{C}$ at the mixing valve. Since the thermostats are calibrated to a specific water temperature, water running through the radiators at a lower temperature results in a lower room temperature.

(2) Quick heat. In order to restore building temperatures to normal as people wake up, a quick heat feature is implemented. In the five minutes following termination of night setback, two things happen. Pump No. 1, which has a higher pump capacity, is engaged so that more water 
is circulated through the radiators. Then the mixing valve is disabled so hoiter water is circulated through the radiators. In essence, the quick heat feature circulates hotter water, faster.

(3) No heat. All heating pumps are turned off for the non-heating season (May- October).

(4) More heat. If more heat is needed, the higher-capacity pump, Pump No. 1, can be energized in place of the standard pump, producing more heat in each room.

DHW circulating pumps. DHW is circulated continuously through DHW pipes during waking hours so that hot water is available immediately at the spigot. This feature conserves water. The DHW circulating pumps are turned off during normal sleeping hours. Hot water is still available, but it may take longer to get to the consumer. The circulating pumps may be turned off to assist load shedding. However, this is not done currently.

The hardware and software work together to perform local and central monitoring and control. The hardware architecture is shown in Fig. 1.

The district heat system may be divided into two subsystems: the primary subsystem, which is owned and operated by the city, and the secondary subsystem, which is operated and maintained by the Army (refer to Fig. 2). The primary district-heating system begins at the gas-fired districtwater-heating plant. The source water temperature depends upon heating requirements which are a function of time of day, day of the week, and weather. The building's district-heat water temperature is regulated by controlling the flow of water through the heat exchanger.

The secondary system starts at the heat exchanger. There are several "zoned" heating circuits in a building that supply heat to different sides of the building. Zoning radiators helps achieve an even distribution of heat within a building. 


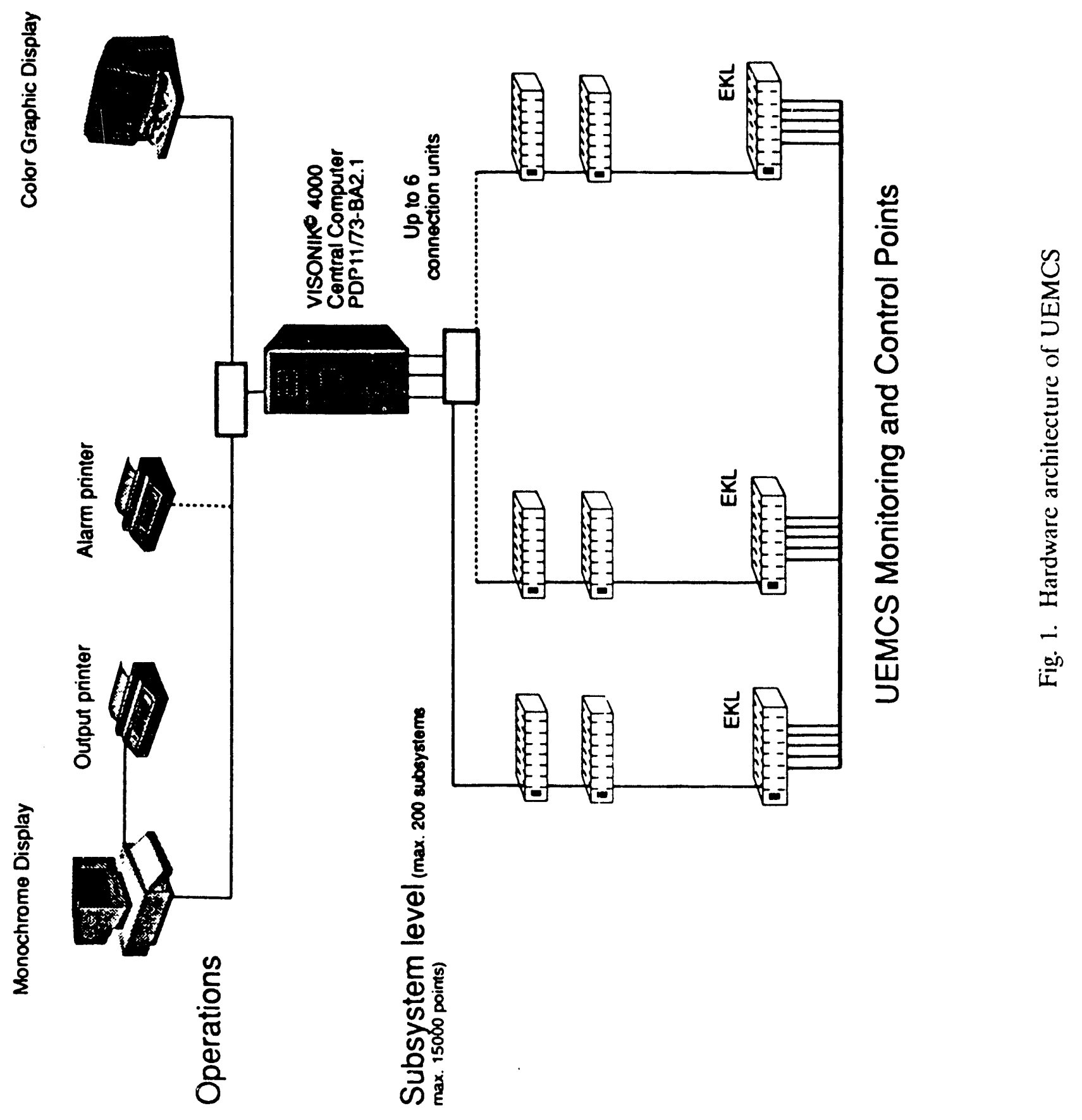




\section{Primary}

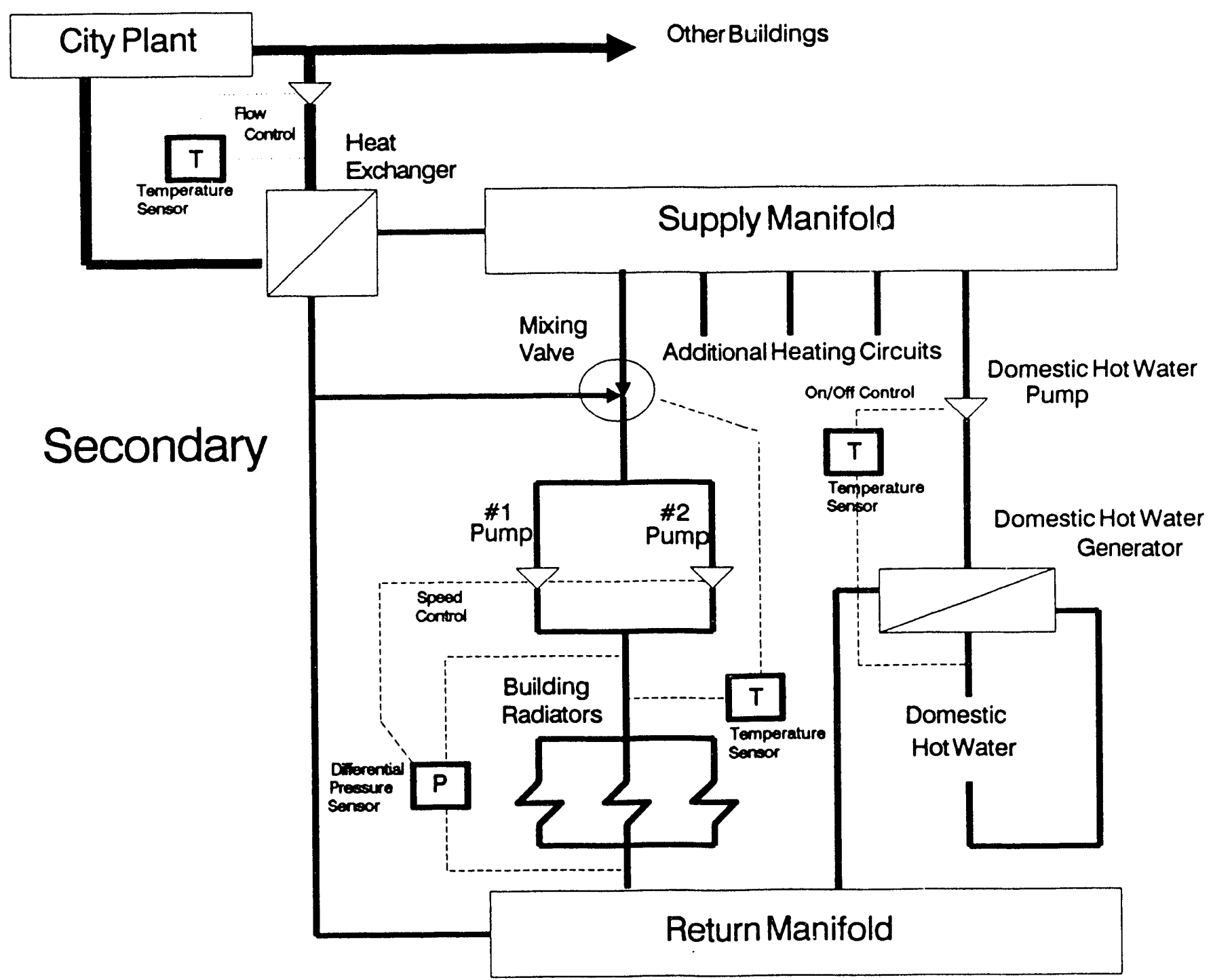

Fig. 2. Schematic of the Goeppingen district heat system 
The heat delivered to each zone is regulated by temperature and pressure control. A mixing valve combines hot water from the heat exchanger with cooler return water, which has already been through the radiators in the building, to provide the correct water temperature. The pressure controf sensor adjusts the rate of water flow through the zone. The pressure sensor effectively determines how much water is flowing through all radiators in the zone and compensates so that adequate heat is available to each individual.

The third and final control is the individual thermostat on the radiator. The thermostat is calibrated to a specific water temperature, so a higher or lower water temperature alters the room temperature. 


\section{ASSESSMENT OF SITE AND PHYSICAL CONDITIONS}

This section provides a brief overview of the physical condition as well as other energy related observations at the specific sites and facilities visited. In general, all facilities visited under UEMCS control were clean and well maintained. With the installation of district heat and hot water heating, the operating environment for the UEMCS equipment has been made less severe. As a result the UEMCS equipment should now have an increased life.

\subsection{GOEPPINGEN-COOKE BARRACKS AND FAMILY HOUSING}

Cooke Barracks was equipped with district heat during 1985 and 1986. The transfer station, control systems, and heating distribution in most of the buildings were replaced between 1982 and 1988. UEMCS cabling has been installed for all of the buildings in the Cooke Barracks area with the exception of those on Ware Circle, Buildings 253,257 , and 109 . This cabling prepared nearly all the buildings for UEMCS monitoring and control. The old Noncommissioned Officers Club, building No. 244 , was equipped with a new oil-heating plant in 1988 with no plans for connection to the UEMCS in the foreseeable future.

The family housing area was connected to district heat during 1985 and 1986 . The transfer stations and control systems were replaced between 1986 and 1987. The heating distribution systems are in good condition with the exception of the ones in Buildings $311,312,313,326,327,328$, and 329. However, old heating lines still exist between Buildings 302 and 303, 324 and 320, 324 and $323 / 322$, and 302 and 301. UEMCS cabling is installed for all family housing buildings with the exception of Buildings 3210, 333, and 336.

In 1989 the Cooke Barracks and family housing area had a combined area of approximately two million square feet of building space with about one million square feet connected to district heat. 
The control center for the Goeppingen UEMCS is located in building 110, the same building that houses DEH personnel. The control center has both a color monitor and a monochrome monitor, a keyboard console, and hardwire communication lines coming from the other buildings at Goeppingen. The UEMCS utilizes a DEC PDP 11/73. The computer's respcase time to console commands was adequate. Documentation could not be found to reveal the amount of main memury the PDP $11 / 73$ has, though indications are that it is between $256 \mathrm{~K}$ and $1 \mathrm{M}$ bytes. If response time needs to be improved as more equipment is added to the UEMCS, consideration should be given to expanding the computer's main memory.

The district heat system is well designed, implemented, and maintained. The heating system was correctly chosen as the first system to be implemented to save energy and money. Most of the benefits derived are attributed to this installation. The manner in which the system is operated takes advantage of the district-heat rate structure. For example, the absence of demand charges permits the economic application of quick heating, which allows $\mathrm{DEH}$ to wait until the last minute to restore normal room temperatures for morning occupancy. However, there the system could be improved by adding additional instrumentation and monitoring to determine how much heat each building is using. Analysis of this data should reveal in which buildings adjustments need to be made to the heating system or the building's utilization.

The electrical system is not connected to the UEMCS. A tour of several substations revealed that these substations are new installations and can be easily connected to the UEMCS. The substations contain transformers, switchgear, and capacitors. The installations are neat and well designed. Capacitor control appears to be sound; however, there are not enough capacitors to keep the power factor near unity. Because the transformers are fixed-tap transformers, voltage contro! cannot be used as a means of reducing consumption either during peak times or as a conservation measure. 
Water consumption at Goeppingen is considerably higher than it is at Schwaebisch Gmuend. However, when the square footage of the facilities is considered, Goeppingen's rate of consumption becomes comparable to that of the Hardt and Bismarck Kasernes. The high cost of water in Germany suggests poiential benefits from monitoring its consumption with the UEMCS. Monitoring should be relatively inexpensive and could also assist in detecting water leaks.

A general tour of the buildings revealed that windows are normally open, even during the winter. The reason appears to be that buildings have inadequate ventilation. Since retrofitting buildings to assure adequaie ventilation is probably prohibitively expensive, apparently not much can be done to reduce these heat losses. Buildings generally have 12 in. of insulation in the attic area and eaves. No attempt has been made to retrofit walls with insulation. The naturai block walls permit the building to "breathe" a little. Windows have been replaced and the window system is cxcellent. The windows are double insulated and when closed are very tight.

\subsection{SCHWAEBISCH GMUEND, HARDT KASERNE, FAMILY HOUSING, AND BISMARCK KASERNE}

Hardt Kaserne was connected to district heat in 1985 and 1986. The heating system, as well as the transfer station and control system, was replaced in 1986 and 1987. Also, cables for UEMCS were installed at this time.

Bismarck Kaserne is heated by two oil-fired boilers that produce low-pressure steam. The boilers are adequately maintained but are aging and therefore prone to breakdown. Spare parts are sometimes difficult to obtain. The transfer stations, control systems, and heating distribution systems were replaced during the 1984-1989 time frame. The long-distance steam lines are 50 years old and must be replaced within the next 8 years. The oil-fired units need to be replaced by district heat, and 
at the same time the secondary system must be converted from steam to hot water. Cables for the UEMCS are not yet installed, but installation is planned with the conversion projects mentioned above.

The Family Housing area was connected to district heat during 1985 and 1986 . The transfer stations and control systems were replaced in 1986 and 1987 . The heat distribution systems, with the cxception of Buildings 708, 716, and 717, were replaced between 1984 and 1988. Cable for the UEMCS has also been installed. Old heating lines without monitoring remain between Building 711 and Buildings $712,713,714,715,716$, and 717 .

In 1989, Hardt Kaserne contained 390,000 $\mathrm{ft}^{2}$, Bismarck Kaserne contained 450,000 $\mathrm{ft}^{2}$, and the family housing area had $680,000 \mathrm{ft}^{2}$ of building space.

These facilities appeared to have lower occupancy rates than those at Goeppingen. The district heat is not connected to the UEMCS. However, when it was first installed, the UEMCS computer was located at Schwaebisch Gmuend. The computer monitored and controlled the district heat system there. A telephone line is all that is required to hook these facilities up to the UEMCS. However, the Goeppingen DEH has been unable to get the phone line authorization despite waiting four years. The local controls and district heat equipment are located in spacious boiler rooms. These facilities were not as clean as Goeppingen's, but they are just as functional.

Water consumption per square foot is comparable to that at Goeppingen. Monitoring water consumption from Hardt and Bismarck facilities may be added to the UEMCS, especially if the latter facility is converted to district heat.

Power factor comperisation appears to be adequate at Hardt Kaserne, but needs to be improved for Family Housing and Bismarck Kaserne. 


\section{ANALYSIS OF ENERGY CONSUMPTION AND COSTS}

This section examines actual annual energy consumption and costs. Observed trends are correlated with site improvements, due to UEMCS and other conservation efforts.

Figure 3 shows the heat energy consumption for the total community, which includes both Goeppingen and Schwaebisch Gmuend. This data was used to define the preconversion year (1984), the transition years $(1985,1986$, and 1987), and the postconversion years $(1988,1989$, and 1990). All heating fuels purchased were converted to a common base of MBtu. No historical values of installation building square footage were available with which to normalize the data, but the trends are nevertheless revealing. Electrical consumption is discussed separately because it is not associated with the UEMCS or district heating system.

Figure 3 clearly shows the decreasing purchases of coal and oil in 1986 and 1987 . It also clearly shows the increasing consumption of district heat energy between 1985 and 1987 . Because coal and oil are purchased in bulk and stored, 1985 is counted as a conversion year. (Bringing district heat on-line is preceded by burning up the coal and fuel oil reserves.)

The total community data pictured in Fig. 3 is broken down in the next two figures. Heat energy consumption for Goeppingen is shown in Fig. 4 while Schwaebisch Gmuend's consumption is pictured in Fig. 5 .

Goeppingen's fuel purchases reflect declining purchases of oil and coal from 1984 through 1987. From 1988 on, no coal is purchased, and oil purchases are minimal and stable. Also, district heat is shown to be partially operational in 1986. Energy consumption from 1988 through 1990 is very stable.

As shown in Fig. 5 Schwaebisch Gmuend's oil purchases decreased between 1984 and 1987. This figure shows that the district heat became partially operational during 1986 . Oil purchases were 

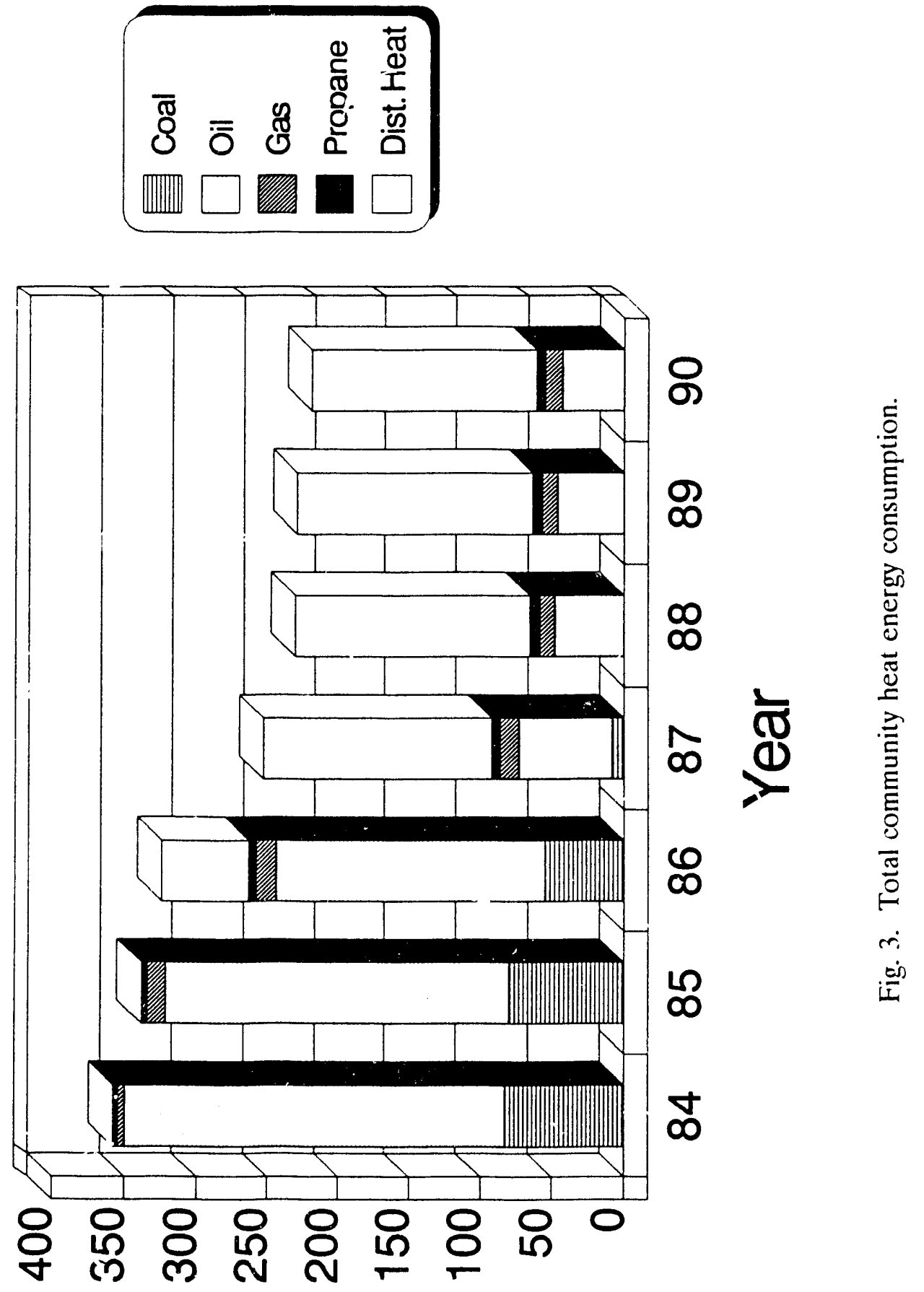

(spuesnou1) nłgw 


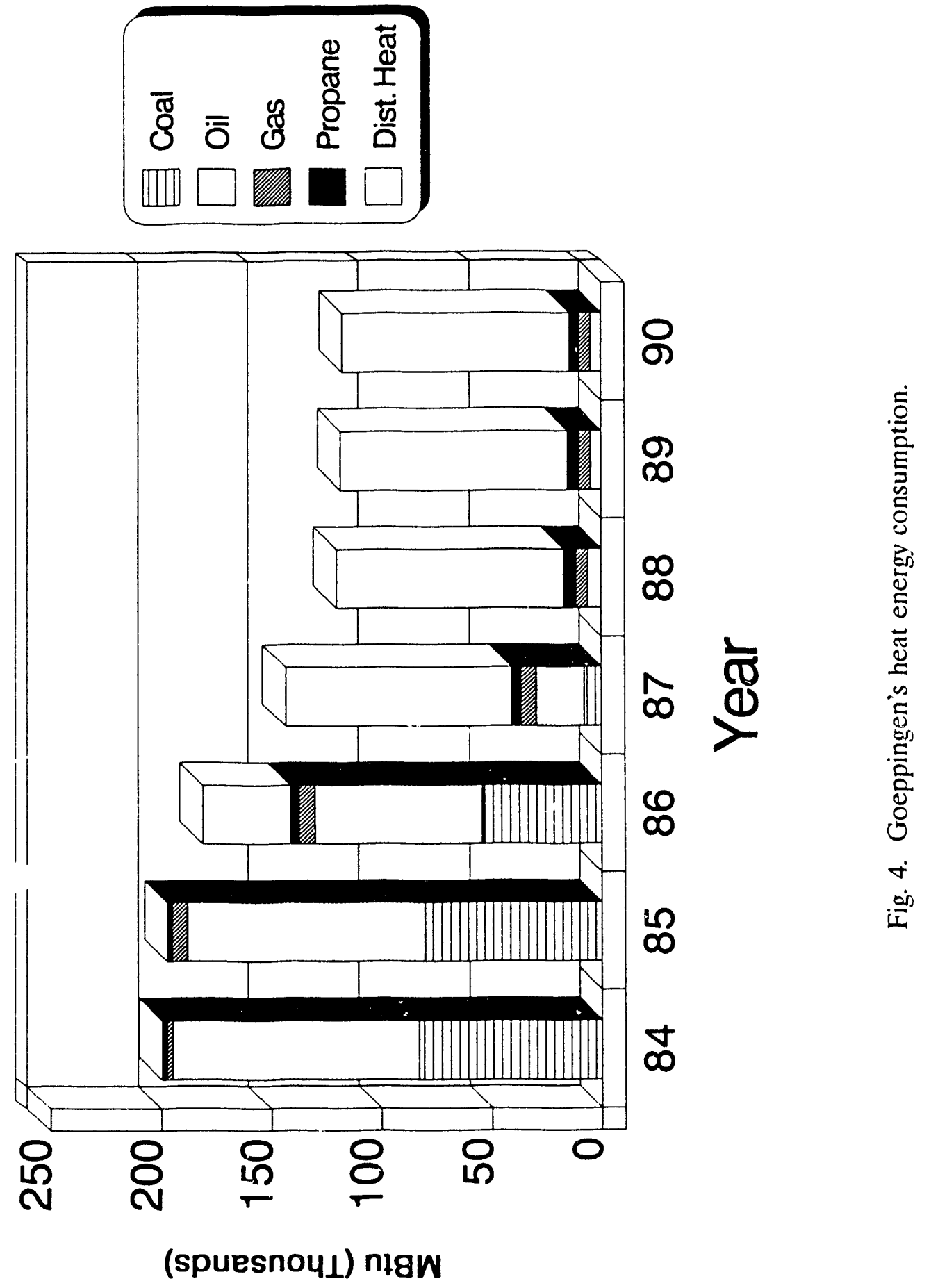




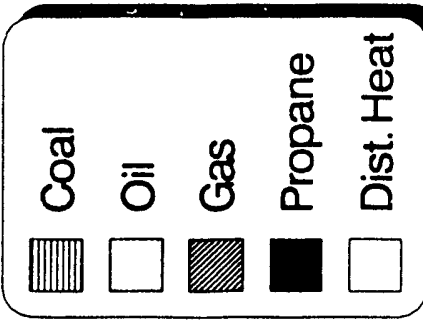

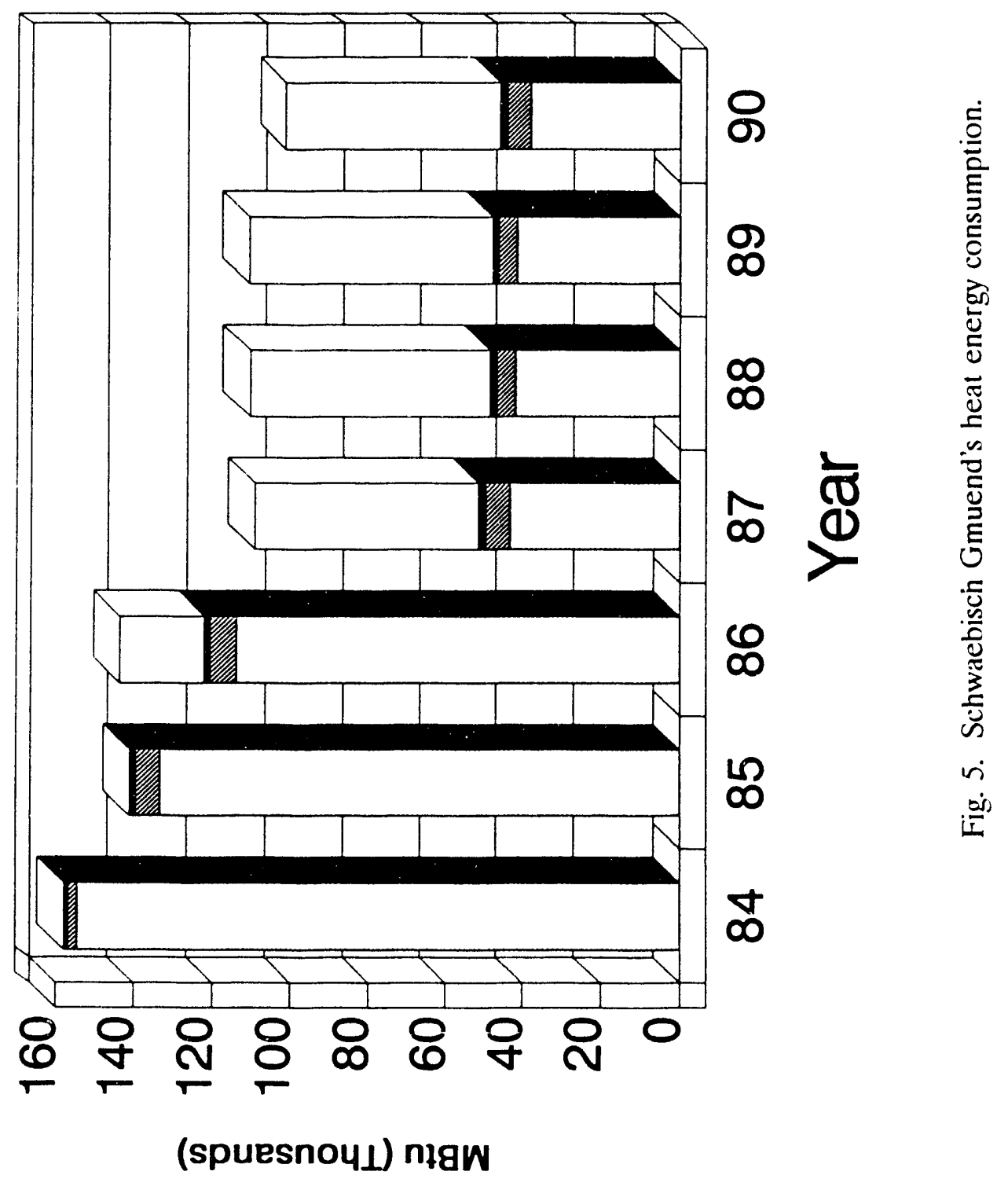


lower during 1985 because the oil reserves were burned in anticipation that a portion of the heating load would be assumed by district heat in 1986 . Energy utilization is shown to be relatively stable between 1987 and 1990.

Electrical consumption is shown in Fig. 6. Though the electrical system is not under UEMCS control, data are presented which will be used in the next section to project savings resulting from electrical system conservation measures. This figure shows steadily increasing consumption in Goeppingen from 1984 through 1989. Consumption growth leveled off between 1989 and 1990 .

Schwaebisch Gmuend shows increasing electrical consumption from 1984 through 1987. Since 1987, electrical consumption has stabilized, even decreasing slightly in the last two years.

Electrical costs are pictured in Fig. 7. In 1989, demand charges were 53\% of energy charges. The peak demand usually occurs early in the year, say January or February. Peak denand charges set in January or February are added onto the bill for each of the remaining months of the year. Any reduction in demand during the peak demand month results in savings which are multiplied by 11 or 12 (each remaining month of the year).

Annual energy and demand charges for each of the billing points are included in the tables which follow. Goeppingen's charge comes from the billing points at Cooke Barracks, the Hohenstaufester Family Housing Area, and the Buergerhoelzle Family Housing Area. Goeppingen's annual costs are shown in Table 1. Schwaebisch Gmuend charges come from the billing points at Hardt Kaserne, Family Housing, and Bismarck Kaserne. Schwaebisch Gmuend's annual costs are shown in Table 2. All costs are in 1000DM.

Total energy costs (both fuels and electricity) for Goeppingen, Schwaebisch Gmuend, and the total community are shown in Figs. 8, 9, and 10, respectively. Costs provided by the facility were in U.S. dollars. The DM values portrayed in Figs. 8-10 were converted from dollars using average annual exchange rates provided with data from Heidelberg, thus, some accuracy may be lost. 
All three figures show a large peak in 1986 with decreasing cost thereafter. However, the curves do not reflect actual consumption because the district heating charge is composed of an investment charge (to repay the cost of constructing the central district-heating plant) and a consumption change, which itself has an annual minimum. The peak in 1986 is caused by application of the minimum district-heating charge for the year, despite the facility's not having fully converted to its use. Thus, fossil fuels are yet being used, and paid for, in areas soon to be served by district heat. The years after 1986 also have somewhat inflated charges due to these same features of the billing schedule. 


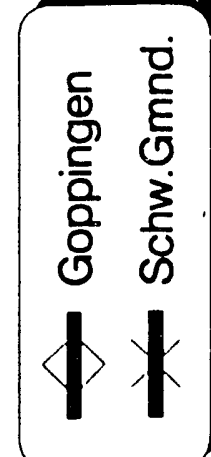

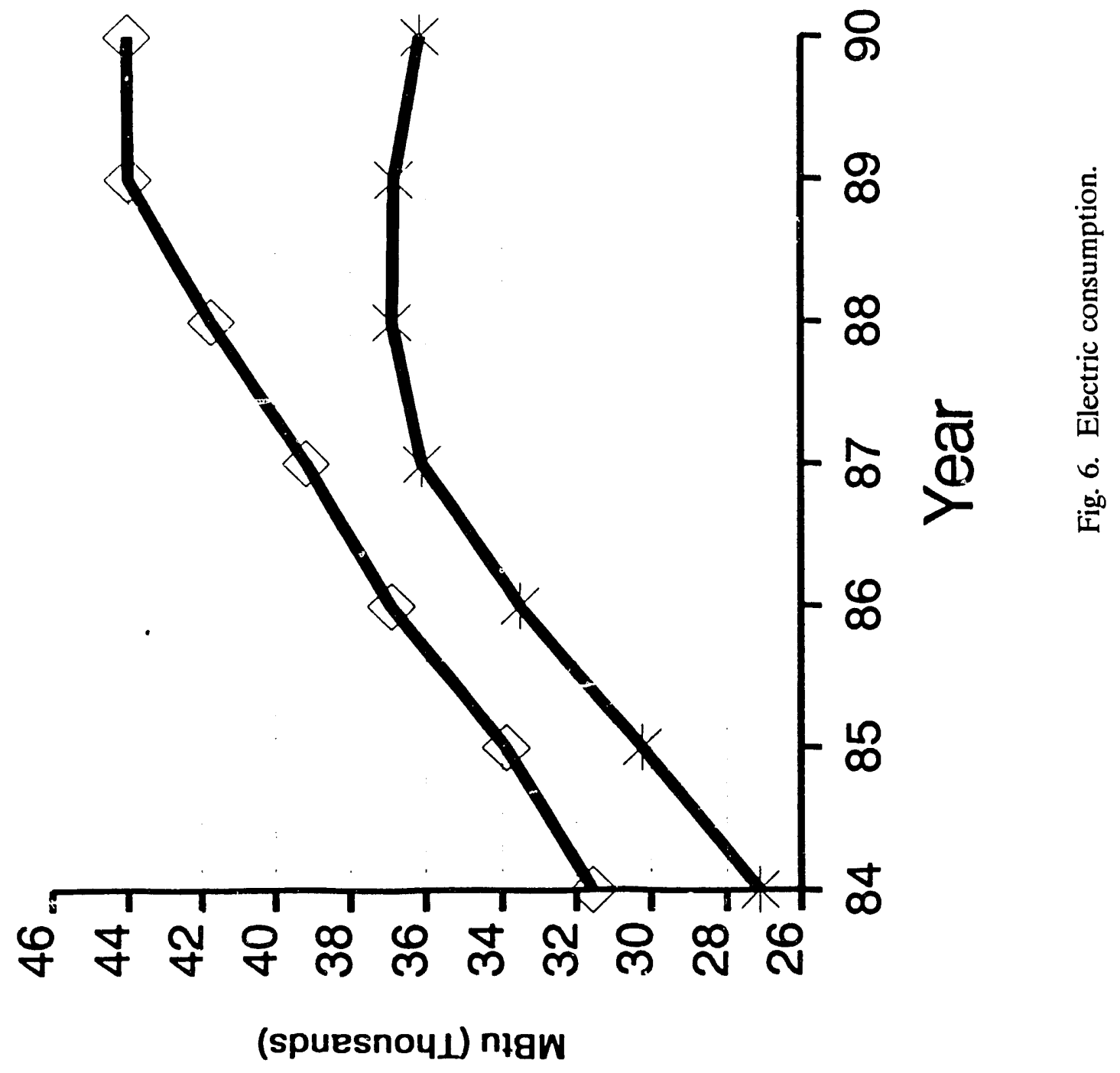




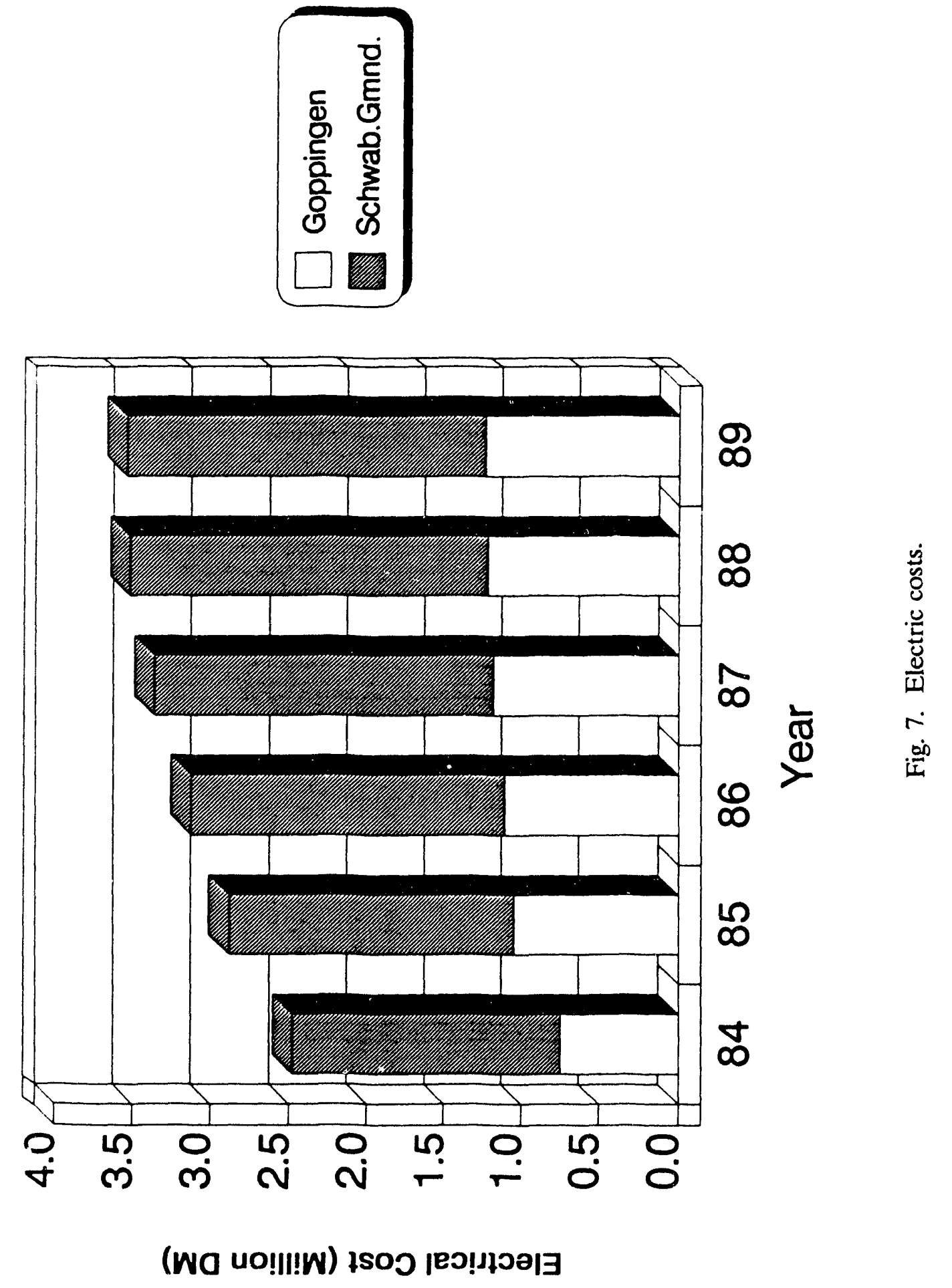




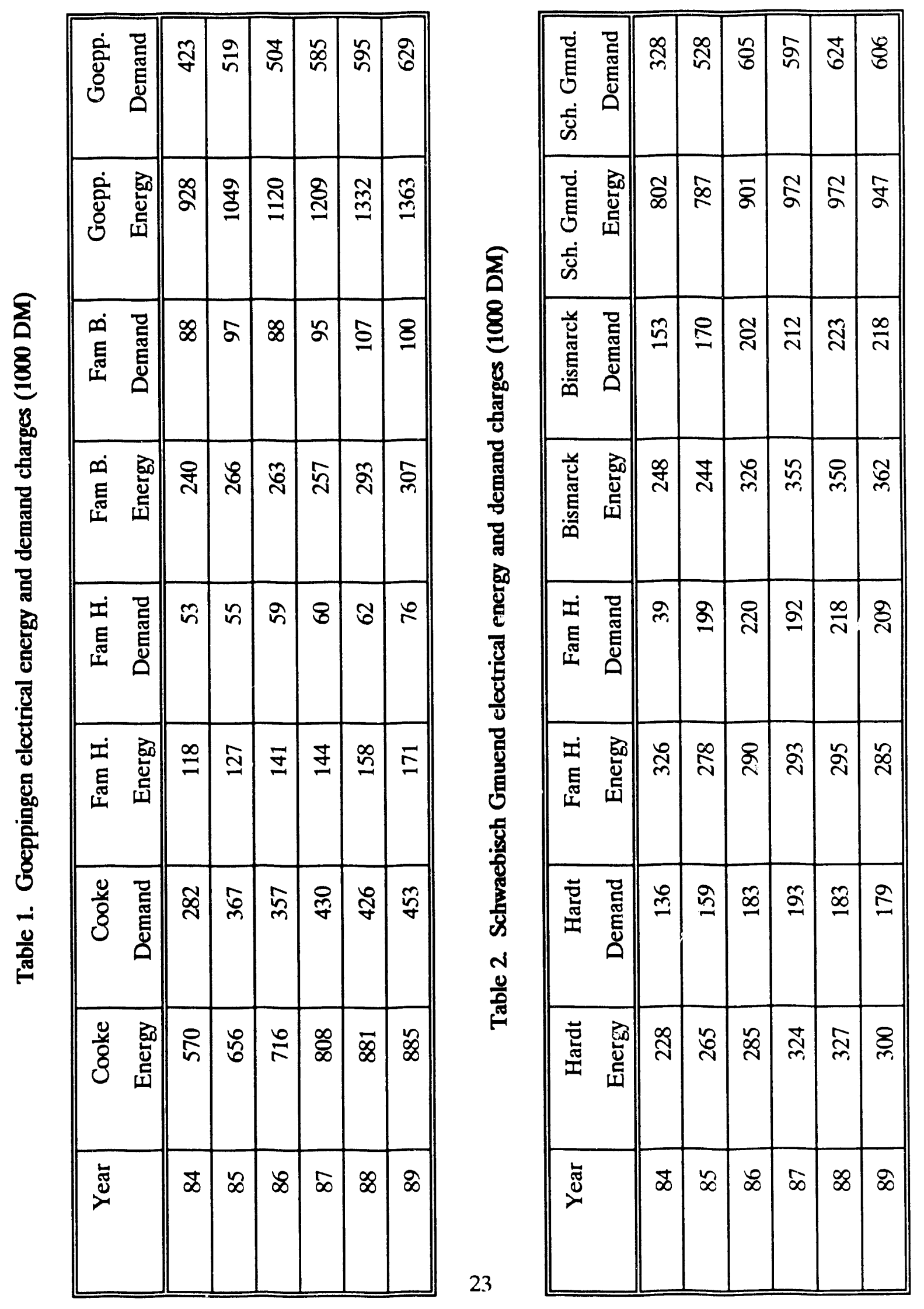



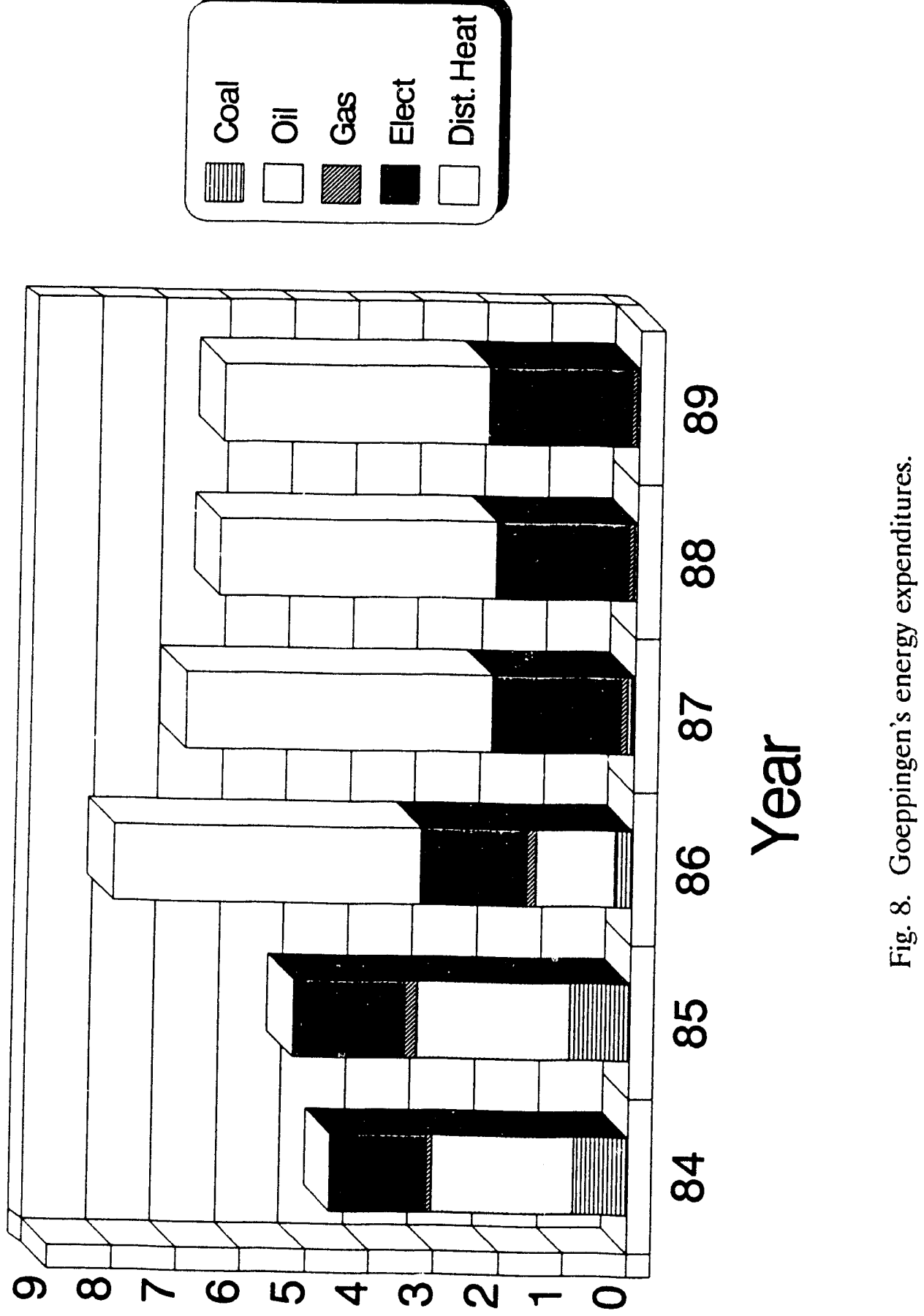

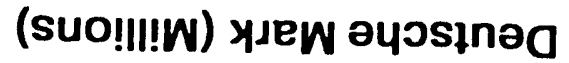



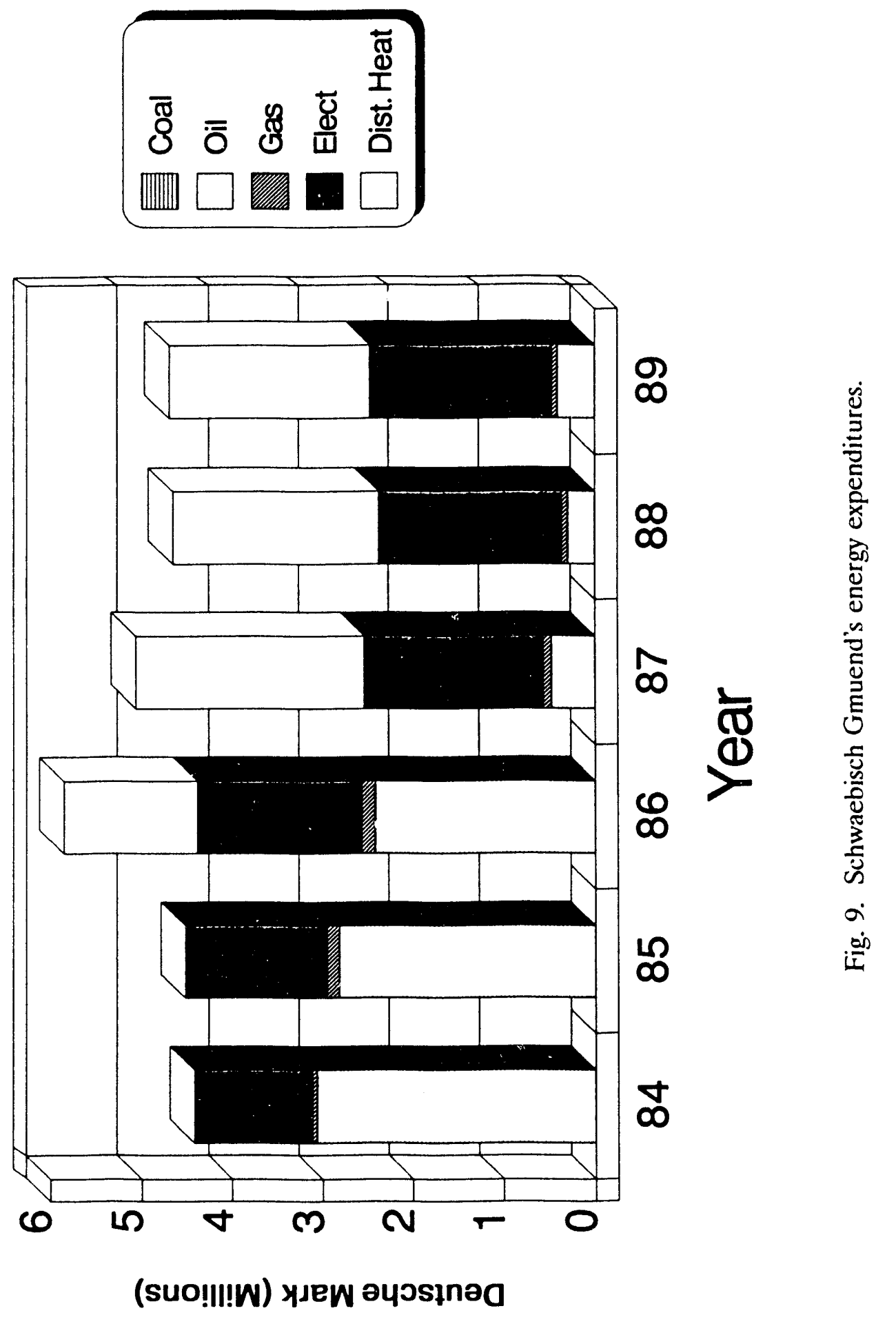


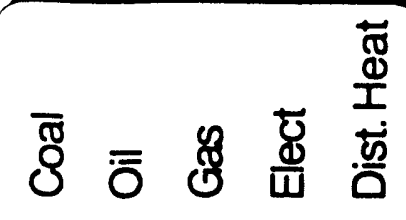

$$
\begin{aligned}
& \text { 四口曰⿴囗十口 }
\end{aligned}
$$

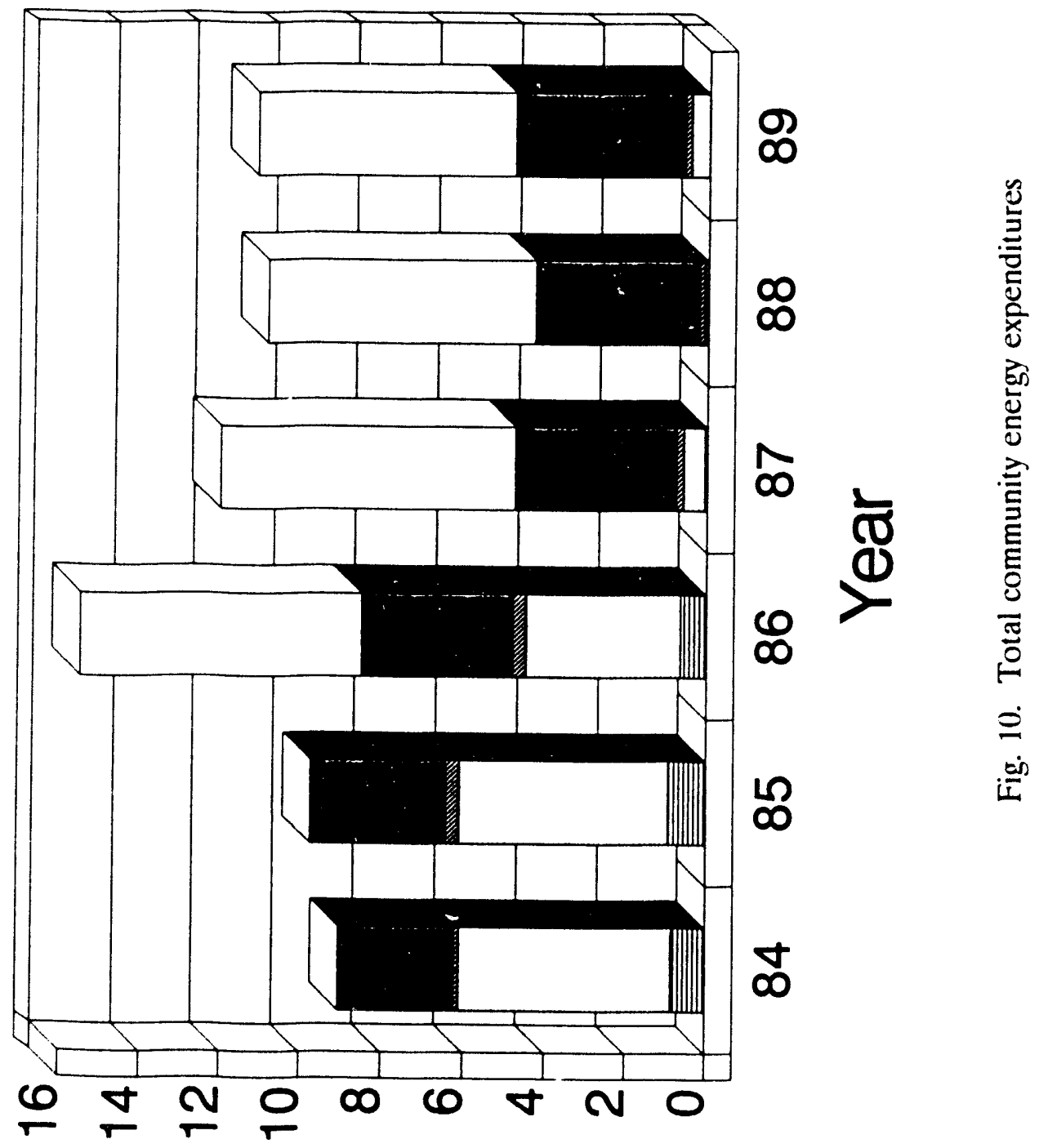

(suo!I!!W) yมеพ әบวsłnəa 


\section{ANALYSIS OF CONSERVATION MEASURES IN EFFECT}

The trends in energy consumption described in Sect. 5 demonstrate well the effects of imp' zmenting the district heat and UEMCS systems. However, in order to more fully understand the origins of the trends, the aggregate energy savings must be broken down into savings by individual energy conservation measures. This section summarizes the results of this analysis for the Goeppingen community. The data were insufficient to perform a similar analysis for Schwaebisch Gmuend. Potentially applicable UEMCS measures are defined and discussed in Project Planning, Design, and Acquisitions Guidelines-Utility and Energy Monitoring and Control Systems, (USAREUR). Table 3 includes all the energy savings measures identified in this guideline. Separate columns indicate whether or not these measures are in effect at Goeppingen.

Estimated energy savings attributed to each UEMCS conservation measure currently implemented at Goeppingen are reviewed in Sect. 6.1. Appendix A contains the computations producing these savings estimates. In Sect. 6.2 , these results are tabulated with current charges for district heat and electricity applied to obtain estimated cost savings for the measures. These results are compared with those reported for the Heidelberg installation. Section 6.3 compares historical energy consumption trends with the estimated UEMCS energy savings as well as with savings from two additional energy conservation measures implemented at the same time as the UEMCS-conversion to district heat and installation of radiant heaters-in order to increase understanding of the trends for the installation. Potential labor savings and other non-energy savings are discussed in Sect. 6.4. 


\section{Application \\ Summer/Winter Operation Monitoring \\ Scheduled Start/Stop Program}

Optimum Start/Stop Program

Electrical Power Demand Limiting Program

Day/Night Setback Program

\section{Economizer Program \\ Ventilation and Recirculation Program}

Remote Boiler Monitoring and Supervision

Hot-Water Outside-Air-Reset

Program

Lighting Control Program

District-Heat Demand-Limiting

Progiam

District-Heat Supply Program

Hot-Water Distribution Program

Domestic Hot Water Generator

Program

Heating and Ventilating Unit

Program
In Effect

$\frac{\text { Yes }}{\mathrm{X}} \quad$ No

$\mathrm{X}$ Includes night-time shutoff of domestic hot water circulating pump.

$\mathrm{X}$ District heat is not turned off in the buildings during the heating season.

$\mathrm{X} \quad$ Electrical demand charges are high.

Heating is set back $5^{\circ} \mathrm{C}$ for an average of 6 hours per night. Temperatures are restored to normal using a 5-min. quick-heat cycle when hotter water is allowed to pass through the radiators.

$\mathrm{X}$

$\mathrm{X}$

$\mathrm{X}$

$\mathrm{X}$

$\mathrm{X}$

District heat temperatures in the building are adjusted based on outside air temperature.

Outdoor lighting is controlled by photo cells.

X Demand charges are not part of the district-heat rate structure.

$\mathrm{X} \quad$ Not supplied by a secondary system (see hot-water outside-airreset program).

$\mathrm{X}$

Water temperature is kept constant for each zone. Heating zones are on the opposite sides of buildings and take into account natural heating due to the sun.

Domestic hot water is maintained at a constant temperature. It is not lowered during evening hours.

Buildings that require a lot of ventilation use this feature. 


\subsection{ENERGY SAVINGS ATTRIBUTED TO EACH MEASURE}

Because metered data associated with each measure were not available for Goeppingen, cngineering estimates based on available data, experience, and data obtained in the Heidelberg study were used, as were computational methods supported by the Army Corps of Engineers in Huntsville (NCEL 1982). Estimates are for the Goeppingen complex only, including Cooke Barracks and associated family housing. Data for the Schwaebisch Gmuend facilities were not sufficient to attempt similar estimations. Where required data were missing, assumptions (sometimes broad) were made.

\subsubsection{Day/Night Setback}

The day/night setback program reduces energy consumption in buildings during unoccupied hours. The temperature setpoint is lowered for heating loads and raised for cooling loads for times during which the building is normally unoccupied and reset to normal for times during which the building is normally occupied. The Goeppingen DEH estimates this measure saves $7 \%$ of the total heating energy. Because setback is utilized in only $75 \%$ of the buildings, this value is equivalent to a $9 \%$ savings in those affected. Other published sources (NBSIR 1984, Home Energy 1991, Broders and McConnell 1991) give savings ranging from 11 to $14 \%$, using assumptions consistent with practice at Goeppingen. From these comparisons, the estimated 9\% savings appears conservative. However, computational estimates lead to considerably smaller percent savings. Two methods based on similar assumptions (NCEL 1982 and Illinois 1988) both yield estimates of only 4\% (Sect. A.1).

In conclusion, the amount of savings from use of the night setback measure likely lies between 4 and $14 \%$ of total space heating energy consumption for buildings controlled by the measure, with $9 \%$ the average. For 1989 this savings is equivalent to $7170 \mathrm{MBtu}$. 


\subsubsection{Summer/Winter Operation Monitoring (Switchover)}

The summer/winter operation monitoring program helps accomplish summer/winter switchover. Generally, it provides the means to change operating parameters, alarm limits, and start/stop schedules for each electrical and mechanical system attached to the UEMCS. Another study of EMCS systems at U.S. Army installations found this measure to be the most used EMCS measure at several facilities (Gettings and MacDonald 1988). At Goeppingen, the savings that can be attributed to the UEMCS-controlled cessation and initiation of space heating in the spring and fall relies hevily on how the measure is implemented and what the customary practices were before its implementation, as well as the number and type of facilities connected to the system. An order-ofmagnitude estimate of potential savings yi_lds $1230 \mathrm{MBtu} / \mathrm{year}$ thermal and $500 \mathrm{MBtu} / \mathrm{year}$ electrical cnergy (Sect. A.2). In addition, manpower savings should be attributed to eliminatin ${ }_{i}$ utility personnel's need to individually visit equipment sites.

\subsubsection{Hot-Water Outside-Air-Reset Program}

The hot-water outside-air-reset program adjusts the heating water temperature based on the outside air temperature, reflecting the decreased heating requirements during warmer weather. The lower water temperature reduces heat loss from equipment and piping. At Goeppingen the program adjusts the mixing valves in the delivered heating water lines to mix supply and return water such that the delivered hot water remains at a specified temperature, based on the predicted heating requirements as indicated by the outdoor air temperature. The Naval Civil Engineering Laboratory report remarks that no exact means of quantifying these savings is known (NCEL 1988). However, applying the report's suggested formulas to Goeppingen yields an annual savings estimate of 690 MBtu, less than $1 \%$ of the space heating consumption supplied by district heat for 1989 (Sect. A.3). 


\subsubsection{Hot Water Distribution Program}

This program allows the north and south sides of buildings to receive differing amounts of heat, often necessitated by the difference in solar radiation entering the spaces. An estimate of savings for the measure was produced by determining the difference in passive solar heating available to the north and south sides of buildings in Goeppingen. Only a portion of this energy would be saved, however, because occupints can reduce the heat supplied to their spaces by adjusting the individual radiator valves. Nevertheless, energy would be saved by (1) lessened heat loss from the pipes supplying the spaces that have reduced heating requirements and (2) the elimination of the energy wasted by negligent or absent occupants who do not adjust their radiator valves to compensate for the increased solar heating. If it is assumed that only $20 \%$ of the total amount can actually be saved, the estimate for energy savings yields $390 \mathrm{MBtu} / \mathrm{yr}$ (Sect. A.4).

\subsubsection{Domestic-Hot-Water Generator Program}

This program maintains a selected delivered DHW temperature by switching on and off the pumps providing heating hot water to the DHW generators. There was no history of DHW temperature reduction at Goeppingen (the $\mathrm{DHW}$ temperature is currently set at $45^{\circ} \mathrm{C}$ or $113^{\circ} \mathrm{F}$ ) for which a savings could be determined. Savings for this measure, from simply maintaining this fixed water temperature, is difficult to estimate. Regardless of what mechanism is used, some control would always be present to establish this temperature. A sense of the magnitude of potential effects can be obtained by assuming that the delivered DHW were allowed to increase $9^{\circ} \mathrm{F}\left(5^{\circ} \mathrm{C}\right)$ for $30 \%$ of the time due to lack of accurate control. Under these assumptions, with the current water usage at Goeppingen, savings of $190 \mathrm{MBtu} / \mathrm{year}$ would result (Sect. A.5).

It must be noted, however, that the same lack of control could also result in a lower delivered DHW temperature as well, resulting in a savings of energy but an increase in complaints. 


\subsubsection{Lighting Control Program}

The lighting control program turns lights off based on the time of day and the day of the week. Insufficient data exist to allow computation of savings attributable to the use of photocells to control exterior lighting. A manpower savings is likely associated with the measure, as is some energy savings from eliminating failure to turn off lighting that is no longer required. With the use of photocells, no connection of the lights to the UEMCS exists. Heidelberg reports additional savings by having this connection, allowing easy elimination of even the night-time lighting if allowed. This same situation may also exist at Goeppingen, as suggested by conversation regarding the elimination of required lighting when missiles were no longer stationed at the site.

\subsubsection{Heating and Ventilating Unit Program}

The Heating and Ventilating Unit program controls the delivery of conditioned air to spaces requiring ventilation, such as schools or sports halls. At Goeppingen, outside air is preheated using district-heat hot water. Energy computations were not attempted because insufficient information exists on the various mechanisms utilized in the control of the approximately 120 pumps and associated equipment. At least two of the ventilating units are controlled by direct digital controllers (DDCs), which are not considered part of the UEMCS system.

\subsection{SUMMARY OF UEMCS ENERGY AND COST SAVINGS}

Table 4 summarizes the predicted UEMCS savings computed in Sec. 6.1. The table lists the district heat savings, the associated electrical savings (using a 0.003413 conversion from $\mathrm{kWh}$ to MBtu), and the total MBtu savings for each measure. The right column lists the associated cost savings using average 1989 energy prices for district heat and electricity. 
Table 4. Estimated energy and cost savings attributable to Utilities Energy Monitoring and Control System

\begin{tabular}{|c|c|c|c|c|c|c|}
\hline \multirow[t]{2}{*}{ Measure } & \multicolumn{3}{|c|}{ Energy Savings(MBtu/year) } & \multicolumn{3}{|c|}{ Cost Savings(kDM/year) } \\
\hline & $\mathrm{DH}$ & Elec. & Total & $\mathrm{DH}$ & Elec. & Total \\
\hline Day/Night Setback & 7170 & & 7170 & 274 & & 274 \\
\hline Summer/Winter Switchover & 1230 & 500 & 1730 & 47 & 36 & 83 \\
\hline Hot Water OA Reset & 690 & & 690 & 26 & & 26 \\
\hline Hot Water Distribution & 390 & & 390 & 15 & & 15 \\
\hline Hot Water Generator & 190 & & 190 & 7 & & 7 \\
\hline TOTAL & 9670 & 500 & 10,170 & 369 & 36 & 405 \\
\hline
\end{tabular}

The day/night setback measures saves the majority of energy, approximately $7000 \mathrm{MBtu} / \mathrm{year}$. The summer/winter switchover program has a potential of saving about $1700 \mathrm{MBtu} / \mathrm{year}$. The four remaining measures combined save less than $1300 \mathrm{MBtu} / \mathrm{year}$. The total UEMCS-related energy savings is $10,000 \mathrm{MBtu} / \mathrm{year}$ accounting to cost savings of about DM 400,000/year.

The total predicted UEMCS district heat savings of $9670 \mathrm{MBtu} / \mathrm{year}$, may be compared with the 1989 total district-heat consumption from (Fig. 4) of $102,400 \mathrm{MBtu}$, or about $9 \%$. This percentage could be contrasted with the $27 \%$ space heat savings determined by Heidelberg (Broders and McConnell 1991). The reasons for this large difference in savings are related to the following: 
1. Heidelberg shuts off its DHW circulation pumps during the night-time hours, saving $9 \%$ of its total annual heating-energy consumption. (See Sec. 7 for more detailed discussion.) Goeppingen does not utilize this conservation measure.

2. Heidelberg uses a $16 \%$ savings for day/night setback compared with the value of $7 \%$ used in this report. Using the former value results in a savings of $16,380 \mathrm{MBtu} / \mathrm{year}$ compared with the estimation of $7170 \mathrm{MBtu} / \mathrm{year}$ from this report.

Electrical savings at Goeppingen are greatly reduced from thòse at Heidelberg because of the following:

1. Heidelberg has exterior lighting control connected to the UEMCS, which adds savings to the system. Goeppingen uses individual photocells (not associated with UEMCS) to control its exterior lighting.

2. The DHW circulation pumps at Goeppingen are not shut off during the night.

3. There are no space heaters, air-conditioners, or vending machines connected to the UEMCS at Goeppingen.

4. No DHW generators are shut down overnight at Goeppingen.

\subsection{COMPARISON BETWEEN PREDICTED UEMCS SAVINGS AND HISTORICAL ENERGY CONSUMPTION REDUCTIONS}

Historical data displayed in Fig. 4 indicate that between 1984 and 1989, annual heating energy consumption was reduced from $200 \mathrm{kMBtu}$ to $119 \mathrm{kMBtu}$, or about $81 \mathrm{kMBtu}$. This may be compared with the $9 \mathrm{kMBtu}$ predicted heating savings for the UEMCS, estimated above. Over this period of time, however, not only was the UEMCS system added, but concurrently the district heating system was installed and several buildings were converted to radiant heat. Goeppingen personnel felt that these two measures, together with the UEMCS night setback program, were responsible for the 
majority of the energy consumption reduction between 1984 and 1989. Thus, comparing the historical energy consumption to the UEMCS savings must involve estimating savings from these additional cnergy conservation measures.

Unfortunately, no direct method of estimating the savings for conversion to district heat is availat' 2 . However, estimates for the savings due to implementation of radiant heat in five buildings at Cooke Barracks produce a figure of $6 \mathrm{kMBtu} / \mathrm{year}$ (Sect. A.7). This figure is two-thirds of the total calculated savings estimated for the UEMCS measures.

If the remaining energy reduction from 1984 to 1989 is attributed to conversion to district heat, the estimated savings of this measure becomes $66 \mathrm{kMBtu} / \mathrm{year}$. Thus, even with the approximate nature of the savings computed, we may clearly assume that the conversion to district heat saves the greatest energy. This savings would decrease somewhat if the efficiency of producing the district heat at the plant were included, but would still surpass the other savings.

\subsection{GENERAL ASSESSMENT OF BENEFITS}

As stated in Project Planning, Design, and Acquisitions Guidelines-Utility and Energy Monitoring and Control Systems (USAREUR), UEMCS is not limited to applications that save energy or reduce costs. UEMCS can also be a management tool, supporting the functions of the Utilities Division with such diverse applications as utility cost reduction and utility system planning operation, and maintenance. Most of the non-energy-related savings stemming from the UEMCS at Goeppingen result from maintenance savings.

With the installation of district heat, much of the concentrated local supervision often associated with boiler operation was eliminated. The DEH indicated that the number of boiler operators at the installation had been reduced from 18 to 3 due to implementation of the district heat. What remaining local supervision is needed can now be generally accomplished through the 
UEMCS system. This has greatly reduced the manpower requirements of operating the system, from a decrease in both supervision as well as the need for personnel travel to local sights for inspection of the equipment. Even if an installation operates with a fixed number of billets, personnel are freed to fulfill other assignments which otherwise might be under staffed.

Generally, base personnel appear to accept the UEMCS system. The complaints received result primarily from implementation of Army energy conservation guidelines and not from operation of the UEMCS system, and many of these appear to arise from improper dress of building occupants (shorts in the winter, etc.). Having building space temperature readings available at the UEMCS central station helps in fast identification of problems and, therefore, in timely response to the few user complaints that are received. The two-zone-per-building heating design should also increase occupant comfort as well as save energy by allowing delivered space conditioning to be more closely tied to conditions nearer the end-user.

Support for the UEMCS system by the base command appears to be present. In most cases, sufficient personnel are assigned to operate and maintain the system in its present state. Little, if any, dissension appears to exist between UEMCS maintenance and operations personnel and base command with regard to carrying out energy conservation and utilities management with the system. 


\section{ANALYSIS OF CONSERVATION MEASURES THAT COULD BE APPLIED}

The following discussion describes UEMCS conservation measures that might be installed at Goeppingen in the approximate order of their benefit. Information was often insufficient to estimate potential savings for some of the measures, while for others existing circumstances would likely lead to only small cost savings.

\subsection{CONNECTION OF ELECTRICAL SUBSTATIONS TO UEMCS}

Connecting the electrical substations to the UEMCS allows implementing the demand limiting measure described in Sect. 7.2. Most of the substations at Goeppingen were built recently and designed to accommodate UEMCS. Some local sensors must be added, but much of the cabling is already in place. In light of the current electric demand charges at Goeppingen and the relative ease with which this extension could likely by made, its implementation should be seriously considered.

\subsection{ELECTRICAL-POWER DEMAND-LIMITING PROGRAM}

This program reduces electrical demand by shedding loads during times of peak demand. Cost savings result when the utility rate structure includes charges based on demand as well as consumption, as is the case at Goeppingen. Assuming the electrical switching stations have been connected to the UEMCS, estimates of the potential demand-limiting savings for Goeppingen and Schwaebisch Gmuend yield kDM 54 and kDM 52/year, respectively, or a total savings for both facilities of kDM 106 annually (Sect. A.8). 


\subsection{POWER FACTOR ADJUSTMENT}

Based on the annual demand charges, $84 \%$ of the peak demand at Goeppingen occurred at a $91 \%$ power factor, costing $\mathrm{kDM} 529$ of the total $\mathrm{kDM} 629$ demand charge. Estimates based on increasing the power factor to $99 \%$ yield a potential savings of $\mathrm{kDM} 86 /$ year at Goeppingen. A similar computation for Schwaebisch Gmuend yields an additional savings of kDM 69/year. Thus, a combined savings of kDM 155/year appears possible (Sect. A.9).

\subsection{WATER LEAK DETECTION}

Heidelberg estimates that their leak detection reduces water consumption by $2 \%$ (Broders and McConnell 1991). Applying this percentage to Goeppingen's annual water consumption of $4 \times$ $10^{5} \mathrm{cbm}$ produces a savings of $8,000 \mathrm{cbm}$. At a combined water-sewer cost of $4.6 \mathrm{DM}$, a cost savings of $\mathrm{kDM} 36.8 / \mathrm{year}$ could be expected. This measure should be relatively easy to implemented if Heidelberg's method of single point monitoring at night is used. Additional examination of water use practices at the installation would also likely prove beneficial. A 5\% reduction in use due to water conservation measures would result in nearly a savings of $\mathrm{kDM} 100 /$ year.

\subsection{SCHEDULED STA.RT/STOP OF DHW CIRCULATION PUMPS}

The DHW circulation pumps keep the water at individual taps hot, eliminating the necessity of draining the cool standing water whenever hot water is desired. Because these pumps are shut off overnight, savings result from not having to supply the pumps with electricity during that time, as well as from a smaller heat loss from the DHW pipes because their average temperature is less if they are allowed to cool while the pumps are off. These benefits must be weighed against any additional water usage that may occur due to users running the water at night to get it hot.

Engineering estimates using data from the NCEL (1982) report produce a predicted savings 
of $60 \mathrm{MBtu} / \mathrm{year}$ thermal and $60 \mathrm{MBtu} / \mathrm{year}$ electrical (Sect. A.6). These estimates differ greatly from those used in Heidelberg for what is believed to be the same measure (Broders and McConnell 1991). Here, savings are based on a pipe-heat loss rate of $0.0183 \mathrm{MBtu} / \mathrm{building} / \mathrm{h}$ compared with the prediction from Sect. A.6 of only $0.00136 \mathrm{MBtu} /$ building/h $(6.8 \mathrm{Btu} / \mathrm{h} / \mathrm{ft} \times 200 \mathrm{ft} / \mathrm{building})$. The prediction in this report assumes the hot water pipes are insulated with 1 in. of insulation with an average of $200 \mathrm{ft}$ of such pipe for each building. It subtracts from the savings the energy necessary to reheat the water in the pipes in the morning. If the Heidelberg methodology were applied to Goeppingen, the estimated savings from shutting down the circulation pumps would have been 2500 MBtu/year compared with the $60 \mathrm{MBtu} / \mathrm{year}$ used in this report. There may be failure to understand cxactly what the measure is being applied to in each of the locations. Further examination into the application and assumptions is warranted.

\subsection{CONNECT SCHWAEBISCH GMUEND UEMCS TO CENTRAL STATION}

Though large energy savings may not result from establishing communication between the island UEMCS station at Schwaebisch Gmuend and the UEMCS central station at Cooke Barracks, integration of the two units should eliminate periodic travel between the two installations for the purpose of verifying proper operation of equipment. More rapid identification of abnormal conditions will likely save energy. Also, if the electrical system at Schwaebisch Gmuend were corinected to the UEMCS, additional cost savings could result from implementing demand limiting.

\subsection{LEVEL SENSORS FOR WASTE-OIL SEPARATOR TANKS}

The ability to detect the oil level in the waste oil separator tanks from the UEMCS central station would eliminate relatively frequent visits to the facility and possibly alleviate other potential 
problems associated with lack of surveillance at the sites. This fact was mentioned several times in discussion with base personnel.

\subsection{ADDITIONAL SCHEDULED START/STOP APPLICATIONS}

Other equipment that could be controlled by the UEMCS includes interior or exterior lighting, irrigation, air conditioners, heat pumps, space heaters, and vending machines. The cost effectiveness of implementing their control via the UEMCS depends on the number of each, their location relative to available data transmission media (DTM) channels, and whether any additional remote control units (RCUs) are required. If FM or power-line carrier capabilities already existed having available capacity, connection of such equipment would likely be economical.

\subsection{INSTALLATION OF HIGH-EFFICIENCY EXTERIOR LIGHTING}

Little overall savings will accrue from conversion to high-efficiency exterior lighting unless significant numbers of incandescent or mercury vapor lights exist. On the average, metal halide or high/low sodium lamps produce five times as many lumens/W as incandescent lamps or twice as many as mercury vapor lamps. However, the initial cost of these lamps is significantly greater. Estimates using more precise efficiency data for the specific lamps considered, installation costs, on-time, and lamp lifetime would be required to make definitive decisions.

\subsection{OTHER MEASURES}

Additional UEMCS measures judged to have only minimal or uncertain savings include DHW outside air reset, voltage control, variable-speed pumps (pumps are already variable to a degree), and control/monitoring of the radiant heating plants. The latter has possible labor savings associated with it. 
Two non-UEMCS-related measures having potential for energy savings include expansion of the use of radiant heating in appropriate buildings and conversion of the Bismarck Kaserne to district heat. 


\section{CONCLUSIONS}

The following conclusions are drawn from the site examination and subsequent analysis presented within this report:

- All facilities that were visited and that are under UEMCS control were clean and well maintained. With the installation of district heat and hot water heating, the operating environment for the UEMCS equipment has been made less severe, likely resulting in increased equipment life.

- The conversion to district heat from fossil-fueled boilers at Goeppingen and Hardt Kasernes has produced the majority of energy savings.

- The district beat and UEMCS systems are well designed, implemented, and maintained.

- The UEMCS system at Goeppingen uses local controllers with the central compuier acting in a supervisory capacity.

- The UEMCS system at Goeppingen executes the following applications: (1) day/night setback, (2) summer/winter operation (seasonal switchover), (3) hot-water outside air reset, (4) hot water distribution, (5) DHW generation, and (6) heating and ventilating.

- The day/night setback measure saves the majority of energy resulting from UEMCS implementation, approximately $7000 \mathrm{MBtu} / \mathrm{year}$. The summer/winter switchover program has the potential for saving about $1700 \mathrm{MBtu} / \mathrm{year}$. The four remaining measures combined save less than 1300 MBtu/year.

- The total estimated UEMCS related savings is $10 \mathrm{kMBtu} / \mathrm{year}$ at $\mathrm{kDM} 400$.

- The total annual energy expenses (DM) after installation of the district heat / UEMCS system are greater than before due to the rate structure for the district heat, which includes a 
repayment schedule for construction of the district heating plant and a minimum consumption charge.

- Considerable differences exist between the predicted potential savings from night shutdown of DHW circulation pumps at Goeppingen and the analogous metered savings as determined at Heidelberg. The possibility exists of a misunderstanding regarding the application or assumptions used in each location for this measure. 


\section{RECOMMENDATIONS}

The following recommendations apply specifically to Goeppingen, their UEMCS, and energy utilization. Implementation costs for the recommendations could not be determined for this report. However, the community's facility engineering department should be able to estimate the costs fairly casily.

- Connect the electrical system to the UEMCS and implement demand limiting. Potential savings of $\mathrm{kDM} 106 / \mathrm{year}$ are estimated for the total community.

- Integrate the UEMCS systems at Goeppingen and Schwaebisch Gmuend using available phone lines.

- Install additional capacitors in the electrical system to improve power factor control at Cooke Barracks, Bismarck Kaserne, and Schwaebisch Gmuend family housing. Maximum potential savings of $\mathrm{kDM} 155 / \mathrm{year}$ are possible for the $\mathrm{tr}$ 'ommunity.

- Use the UEMCS to monitor water consumption and identify leaks. Investigate the major water users in an attempt to determine if any conservation measures might be applicable. Examine Heidelberg's single-point water-leak detection method to ascertain its applicability at Goeppingen. Potential savings are kDM 37/year.

- Consider expanding the use of radiant heat to appropriate buildings.

- If the computer response time needs to be improved as more equipment is added to the UEMCS, consider expanding the computer's main memory.

- Continue to study and implement potentially existing UEMCS hardware and software capabilities in the areas of maintenance manager $\_n t$, data analysis, and energy trend and profile generation.

- Expand UEMCS monitoring capabilities to allow determination of energy consumption in 
individual buildings or complexes.

- Support additional examination of the application and assumptions regarding the night shutoff of DHW circulation pumps to provide resolution of savings estimates differences.

The following two recommendations apply generally to implementation of UEMCS by USAREUR:

- Examine potential methods that individual installation UEMCS operators may use to evaluate energy savings resulting from UEMCS programs and other energy conservation measures. Support additional studies to produce USAREUR-wide consistent recommendations on system evaluation. The work already accomplished at Heidelberg and that available through previous Army publications provides an excellent starting point for such a study.

- Explore additional means of communicating successes, lessons learned, and potential problems among USAREUR UEMCS operators, allowing the experiences of each to benefit all. 


\section{REFERENCES}

ASHRAE (American Society of Heating, Refrigerating and Air-Conditioning Engineers) 1985. Handbook of Fundamentals, Atlanta, GA.

Broders, Martin A. and Benjamin W. McConnell 1991. Evaluation of the Computerized Utilities Energy Monitoring and Control System Installed at the U.S. Army, Europe, 26th Support Group, Heidelberg, Germany, ORNL/CON-320, Martin Marietta Energy Systems, Inc., Oak Ridge National Laboratory.

Gettings, Michael B. and J. M. MacDonald 1988. Energy Monitoring and Control Systems (EMCS) at Army Installations-Initial Effectiveness Evaluation, ORNL/CON-259, Martin Marietta Energy Systems, Inc., Oak Ridge National Laboratory.

"Good News on the Setback Front," 1991. Home Energy, V. 8(1).

Illinois 1988. Home Weatherization Assistance Program Whole House Energy Audit, Illinois Department of Commerce and Community Affairs, Illinois Home Weatherization Assistance Program.

NBSIR (National Bureau of Standards) 1984. Performance and Selection Criteria for Mechanical Energy Saving Retrofit Options for Single-Family Residences, NBSIR84-2870, U.S. Department of Commerce.

NCEL (Naval Civil Engineering Laboratory) Standardized EMCS Energy Savings Calculations, 1982. CR82.030, Department of the Navy.

USAREUR (U.S. Army, Europe) undated. Project Planning, Design and Acquisition Guidelines-Utility and Energy Monitoring and Control Systems, Directorate of Engineering and Housing. 


\section{APPENDIX A: ENERGY SAVINGS CALCULATIONS}

\section{A.1 DAY/NIGHT SETBACK}

Estimates of energy savings due to UEMCS implementation of this program could be determined in several ways. Goeppingen $\mathrm{DEH}$ estimates a $7 \%$ savings for a $5^{\circ} \mathrm{C}\left(9^{\circ} \mathrm{F}\right)$ setback of $42 \mathrm{~h} /$ week. A National Bureau of Standards report (NBSIR 1984) lists a $7 \%$ savings for a $3^{\circ} \mathrm{C}$ setback (length of setback not specified) that would be equivalent to an $11 \%$ savings at $5^{\circ} \mathrm{C}$. The magazine Home Energy ("Good News..." 1991) gives an $11 \%$ savings for 8-h setback of $10^{\circ} \mathrm{F}\left(5.5^{\circ} \mathrm{C}\right)$. Last, Heidelberg (Broders and McConnell 1991) uses a $14 \%$ savings (equal to $16 \%$ of energy already reduced by the savings).

Computational estimates, however, lead to considerably smaller savings. Using equations generated by the Navel Civil Engineering Laboratory (NCEL 1982), the calculation for savings is estimated to be

where

$$
\text { Savings }=\mathrm{BTT} \times \mathrm{A} \times \text { weeks } \times \mathrm{h} \times \Delta \mathrm{T}_{\mathrm{sb}} / \mathrm{eff},
$$
$\mathrm{BTT} \times \mathrm{A}\left(\mathrm{BTU} / \mathrm{h} \cdot{ }^{\circ} \mathrm{F}\right)=$
the average building thermal transmission factor times area, taken to be $0.235 \mathrm{Btu} / \mathrm{h} \cdot \mathrm{ft}^{2} .^{\circ} \mathrm{F}$ representing an average
weeks $=$
$\mathrm{h}=$
$\Delta \mathrm{T}_{\mathrm{sb}}\left({ }^{\circ} \mathrm{F}\right)=$
eff $=$ building with attic insulation installed.
number of weeks in the heating season,
number of hours per week the setback is in effect, the number of degrees $F$ of the setback, the efficiency of heat delivery from the purchased source.

Assuming the $6 \mathrm{~h} /$ night setback and a heating season of 34 weeks (used in Heidelberg's estimates) the savings calculation becomes

$$
\begin{aligned}
& \text { Savings }=0.235 \mathrm{Btu} / \mathrm{h} \cdot \mathrm{ft}^{2} \circ^{\circ} \mathrm{F} \times\left(1 \times 10^{6} \mathrm{ft}^{2}\right) \times 34 \text { weeks/year } \times 42 \mathrm{~h} / \text { week } \times 9^{\circ} \mathrm{F} / 0.80=3775 \\
& \text { MBtu/year. }
\end{aligned}
$$

This would be the savings if all buildings connected to the district heating had the above setback scheme implemented. The value represents only $3.7 \%$ of the estimated 1989 district heat consumption for space heating.

A second computational method yielding a fractional savings directly has been used in the Illinois Home Weatherization Assistance Program (Illinois 1988). The savings fraction is computed as

$$
\mathrm{f}=\mathrm{h} \times 0.8 \times \Delta \mathrm{T}_{\mathrm{sb}} /(168 \times \Delta \mathrm{T})
$$

where $h$ and $\Delta T_{s b}$ have the same definition as before and $\Delta T$ is the difference between the indoor average air temperature and the average winter outdoor air temperature. Though this latter 
parameter is difficult to determine, it will be assumed equal to $70^{\circ} \mathrm{F}-20^{\circ} \mathrm{F}=50^{\circ} \mathrm{F}$. Thus, the procedure would produce an estimated fractional savings of

$$
\mathrm{f}=42 \mathrm{~h} / \text { week } \times 0.8 \times 9^{\circ} \mathrm{F} /\left(168 \mathrm{~h} / \text { week } \times 50^{\circ} \mathrm{F}\right)=0.036
$$

or $3.6 \%$, oddly close to the $3.7 \%$ computed by the first method. The two equations are related, with agreement of their results reflecting a consistent choice of BTT $\times$ A and $\Delta \mathrm{T}$.

\section{A.2 SUMMER/WINTER OPERATION MONITORING (SWITCHOVER)}

An order-of-magnitude estimate for the savings resulting from this measure can be made using an average building thermal-transmission factor times area, BTT $\times \mathrm{A}$, and a modified savings equation for scheduled start/stop (NCEL 1982).

where

$$
\text { Savings }=\mathrm{BTT} \times \mathrm{A} \times \Delta \mathrm{T} \times \mathrm{t} / \mathrm{eff} \text {, }
$$

$$
\begin{aligned}
& \Delta \mathrm{T}\left({ }^{\circ} \mathrm{F}\right)=\quad \text { the average difference between inside air and outside air temperatures during } \\
& \text { the period that switchover eliminates the supply of heating, } \\
& t(h)=\quad \text { the time during which heating would have been supplied had switchover not } \\
& \text { occurred automatically, } \\
& \text { eff }=\quad \text { efficiency of heat delivery from the purchased source. }
\end{aligned}
$$

The $\Delta \mathrm{T}$ will not be large because switchover occurs during the swing months when outside temperatures are already moderate. A value of $20^{\circ} \mathrm{F}$ will be used. To estimate the number of hours applicable, assume that shutoff of the heating occurs 3 weeks earlier in the spring and is accessible 3 weeks later in the fall, with heat being supplied $5 \mathrm{~h} / \mathrm{d}$ during this time. Assume also an efficiency of $80 \%$ for distributing the city's hot water through the installations's system. Note that this does not account for the district plant efficiency. Thus,

Savings $=0.235 \mathrm{Btu} / \mathrm{h} \cdot \mathrm{ft}^{2} \cdot{ }^{\circ} \mathrm{F} \times\left(1 \times 10^{6} \mathrm{ft}^{2}\right) \times 20^{\circ} \mathrm{F} \times 6$ weeks/year $\times 7 \mathrm{~d} /$ week $\times 5 \mathrm{~h} / \mathrm{d} / 0.8=$ $1230 \mathrm{MBtu} / \mathrm{year}$.

Furthermore, if the pumps are no longer running during this time, an additional electrical savings accrues. Assuming 540 pumps at $500 \mathrm{~W}$ each that are now shut down for an additional 6 weeks/year yields

Savings $=290$ pumps $\times 0.5 \mathrm{~kW} /$ pump $\times 6$ weeks/year $\times 168 \mathrm{~h} /$ week $=146,000 \mathrm{kWh} /$ year

in electrical savings. This is equivalent to $500 \mathrm{MBtu} / \mathrm{year}$. Therefore, the summer/winter switchover measure could potentially save $1230 \mathrm{MBtu} / \mathrm{year}$ thermal and $500 \mathrm{MBtu} / \mathrm{year}$ electrical energy.

\section{A.3 HOT-WATER OUTSIDE-AIR RESET}

The Naval Civil Engineering Laboratory report (NCEL 1988) remarks that no exact means of quantifying these savings is known, but that experience indicates these savings should be a function 
of the annual equivalent full-load operating hours and total capacity. The suggested formula for savings due to the hot-water outside-air-reset program is

$$
\text { Savings }=\mathrm{EFLOH} \times \mathrm{eff}_{\mathrm{inc}} \times \mathrm{Cap} / \mathrm{eff} \text {, }
$$

where

$$
\begin{array}{ll}
\begin{array}{l}
\text { EFLOH }(h)= \\
\text { eff }_{\text {inc }}=
\end{array} & \begin{array}{l}
\text { equivalent full-load operating hours, } \\
\text { efficiency increase due to reset (suggested to be } 0.01 \text { if other value not } \\
\text { available), } \\
\text { capacity of heating system, } \\
\text { efficiency of heating system. }
\end{array} \\
\text { eff }= & \text { Btu/h) }
\end{array}
$$

None of these parameters are easily obtainable, with the possible exception of the system capacity. The NCEL report gives a means of computing EFLOH, but information necessary to the computation is not available for European locations. A sample computation of the value for Springfield, Missouri, yields $500 \mathrm{~h}$. If this value is scaled by the factor of Goeppingen's annual heating-degree-days compared with Springfield's, the result is an estimate for Goeppingen's EFLOH of $613 \mathrm{~h}$. Using a capacity of $90 \mathrm{MBtu} / \mathrm{h}$ and the efficiency of the $\mathrm{DH}$ delivery system, 0.8 , gives the following estimate of savings from outside air reset:

$$
\text { Savings }=613 \mathrm{~h} / \text { year } \times 0.01 \times 90 \mathrm{MBtu} / \mathrm{h} / 0.8=690 \mathrm{MBtu} / \text { year. }
$$

\section{A.4 HOT WATER DISTRIBUTION PROGRAM}

This program allows the north and south sides of buildings to receive differing amounts of heat, often necessitated by the difference in solar radiation entering the spaces. To evaluate the potential effect of this program, an estimate of the differing amounts of solar heating available through north- and south-facing building spaces will be computed. The ASHRAE HandbookFundamentals (ASHRAE 1985) lists the average solar insolation passing through various oriented single-pane windows during the 21st day of each month. Summing these values for the months of September through March for north and south orientations, then subtracting the two values and multiplying by the $30 \mathrm{~d} /$ month gives an estimate of the annual difference in yearly solar insolation passing through each square foot of window area facing the two orientations. The result is 0.278 MBtu/year $\mathrm{ft}^{2}$. Given the $10^{6} \mathrm{ft}^{2}$ of building floor area serviced by the district heat, and assuming a 0.1 window-to-floor area ratio, dividing the result into the four cardinal directions leads to an estimate of $2.5 \times 10^{4} \mathrm{ft}^{2}$ of window area in each of the north and south directions. Assume that sunlight is available only $40 \%$ of the daylight hours due to cloud cover and that blinds, etc., block all but $70 \%$ of the remaining sunlight. Then, the estimate for the difference in heating requirements for north versus south oriented spaces becomes

$$
0.278 \mathrm{MBtu} / \text { year } \cdot \mathrm{ft}^{2} \times\left(2.5 \times 10^{4} \mathrm{ft}^{2}\right) \times 0.4 \times 0.7=1,950 \mathrm{MBtu} / \text { year }
$$

This value would be a savings estimate for the measure if (1) without the measure the same amount of heat were supplied to spaces of both orientations, based on the needs of the north facing spaces, and (2) the south-facing spaces simply opened their windows to eliminate the excess heat they were being supplied. With the individual radiator valves present, this situation would not exist. It is likely that only a fraction of this energy would be saved by lessened heat loss from pipes that supply the 
spaces having reduced heating requirements and by the elimination of the energy wasted by negligent or absent occupants who do not adjust their radiator valves to compensate for the increased solar heating. If it is assumed that only $20 \%$ of this amount can actually be saved, the estimate for energy savings yields $390 \mathrm{MBtu} / \mathrm{year}$.

\section{A.5 DHW GENERATOR PROGRAM}

This amount of savings for this control program is difficult to estimate. To obtain a sense of the magnitude of potential effects, assume that the delivered DHW were allowed to increase $9^{\circ} \mathrm{F}\left(5^{\circ}\right.$ C) for $30 \%$ of the time due to lack of accurate control and that $20 \%$ of the total water usage were for DHW. Then, with the current water usage at Goeppingen of $4 \times 10^{5} \mathrm{cbm}$, the energy required to provide this extra heating would be

$0.3 \times 0.2 \times\left(4 \times 10^{5} \mathrm{~m}^{3} /\right.$ year $) \times 35.31 \mathrm{ft}^{3} / \mathrm{m}^{3} \times 62.4 \mathrm{Btu} / \mathrm{ft}^{3}{ }^{\circ} \mathrm{F} \times 9^{\circ} \mathrm{F} \times 1 \mathrm{MBtu} / 10^{6} \mathrm{Btu}=480$ MBtu/year

However, it is unlikely that as much hot water would be required at the higher temperature. The actual savings, therefore, may be more accurately estimated as a fraction of the above value, perhaps $40 \%$, or 190 MBtu/year.

\section{A.6 SCHEDULED START/STOP OF DHW CIRCULATION PUMPS}

Because the DHW circulation pumps are shut off overnight, savings result from not having to supply the pumps with electricity during that time as well as from a smaller heat loss from the DHW pipes (their average temperature is less if they are allowed to cool while the pumps are off).

Using curves available in the NCEL 1982 report, the rate of heat loss from pipes containing water at a given temperature may be established. The pipes are assumed to have a 1.5 -in. diameter with 1 -in. insulation. With the circulation pumps running, the water will remain at a constant $45^{\circ} \mathrm{C}$ $\left(113^{\circ} \mathrm{F}\right)$ temperature. Under these conditions, the curves predict a 6.8 -Btu/h heat loss rate per foot of pipe. No information regarding the length a such pipe exists, but for purposes of this example, we will assume each of the 75 buildings under UEMCS control has an average of $200 \mathrm{ft}$ of pipe. Thus, the heat loss over a 5-h period each night for a year would be

$$
6.8 \mathrm{Btu} / \mathrm{h} \cdot \mathrm{ft} \times 200 \mathrm{ft} / \text { building } \times 75 \text { building } \times 5 \mathrm{~h} / \mathrm{d} \times 365 \mathrm{~d} / \mathrm{year}=186 \mathrm{MBtu} / \mathrm{year} .
$$

In addition, the running of the 170 circulation pumps, each $60 \mathrm{~W}$, for the $5 \mathrm{~h} / \mathrm{d}$ amounts to an electrical consumption of

$$
170 \text { pumps } \times 0.06 \mathrm{~kW} / \text { pump } \times 5 \mathrm{~h} / \mathrm{d} \times 365 \mathrm{~d} / \text { year }=18,600 \mathrm{kWh} / \text { year }
$$

or about $60 \mathrm{MBtu} / \mathrm{year}$ equivalent energy.

Without the pumps running, no electricity is expended and less he.tt is lost from the pipes. Using the same heat loss curves, but integrating over a 5 -h period with a cons antly decreasing water 
temperature in the pipes, this heat loss is seen to be only $126 \mathrm{MBtu} / \mathrm{year}$, compared with the 186 MBtu/year for the pipes at a constant $45^{\circ} \mathrm{C}$ temperature.

Thus, with the pumps shut down for 5-h/night, $186-126=60 \mathrm{MBtu} / \mathrm{year}$ less thermal and $60 \mathrm{MBtu} / \mathrm{yr}$ less electrical energy is expended.

\section{A.7 RADIANT HEAT}

Normal convective heating has been replaced by radiant heating in five buildings at Goeppingen. A propane-fueled boiler supplies hot water to pipes attached to the ceiling of mostly high-bay maintenance buildings. Occupants are warmed by radiant heat exchange between the hot pipes and themselves. This form of heating applies well to buildings with high infiltration where the air temperature would be difficult to keep at a comfortable level. Most of the buildings to which this measure has been applied have large hanger doors through which considerable air leaks, even if they happen to be shut.

The savings for the radiant heat measure was estimated by Goeppingen personnel and the manufacturer, respectively, to be 60 to $70 \%$ of the energy required to heat each building. The combined floor area of the five buildings at Cooke Barracks having radiant heat is about $101 \times 10^{3} \mathrm{ft}^{2}$ or about $10 \%$ of the total square footage of buildings serviced by the district heat at Cooke Barracks. If it is assumed that these buildings would required as much energy per square foot to heat with district heat as the average for the other buildings, the savings from using radiant heat in the five buildings at Cooke Barracks may be estimated as

$$
0.1 \times 102,000 \mathrm{MBtu} / \mathrm{year} \times 0.6=6100 \mathrm{MBtu} / \mathrm{year} .
$$

\section{A.8 ELECTRICAL POWER DEMAND LIMITING PROGRAM}

The potential demand limiting savings can be estimated using (1) the same percent peakdemand reduction achieved by Heidelberg, 8.63\%, and (2) Goeppingen's 1989 demand charge. Since the year's peak demand is used to compute the remainder of the year's demand charge as well as set the base charge for the succeeding year, it will be assumed that this percent reduction may be applied directly to the annual peak-demand charge. Thus, the potential cost savings from demand limiting for Goeppingen becomes

$$
0.0863 \times 629 \mathrm{kDM}=54 \mathrm{kDM} \text {, }
$$

regardless of the demand rate. An analogous calculation for Schwaebisch Gmuend yields about a 52 kDM savings.

\section{A.9 POWER FACTOR ADJUSTMENT}

Based on the annual demand charges, $84 \%$ of the peak demand at Goeppingen occurred at a $91 \%$ power factor, costing $529 \mathrm{kDM}$ of the total $629 \mathrm{kDM}$ demand charge. To estimate an upper 
limit on the possible savings from adjusting the power factor, assume that the factor for all $84 \%$ of the demand may be increased to $99 \%$. The potential savings becomes

$$
(1-0.91 / 0.99) \times 529 \mathrm{kDM}=43 \mathrm{kDM} \text {. }
$$

The increase in power factor also reduces electrical consumption. If it is assumed that the impact is only about half as great as for peak demand reduction, but that each unit consumed costs twice as much, an equal cost reduction may be attributed to electrical consumption. Thus, an estimated 86 $\mathrm{kDM}$ /year savings could result from power factor adjustment at Goeppingen. A similar computation for Schwaebisch Gmuend yields an additional savings of $69 \mathrm{kDM} / \mathrm{year}$. Thus, a combined savings of $155 \mathrm{kDM} /$ year appears possible. 
a. Community

Original Estimate

Community

First Revision

Authorization

Authorization

S-GP-1330-81

$(\$ 1=\mathrm{DM} 2.40)$

S-GP-1327-81

Total

EUD Estimate

$\$ 1,345,100$

$\$ 2,233,000$

$\$ 3,578,100$

740,400

993,000

$1,733,400$

$2,282,069$

$2,340,635$

$4,622,704$

Revised DD Form 1391

$2,673,430$

$2,742,100$

$5,415,530$

b. OMA

$2,673,430$

$1,700,433$

$4,373,863$

Family Housing

$1,041,667$

$1,041,667$

c. FY 83 OMA K account funds are available to fully cover the increase in cost from the original estimate. The funds identified in the original estimate have been obligated by EUD utilizing the indirect construction procedure. Neither project contains OMA L account work.

$\begin{array}{llccr} & & \text { Authorization } & \text { Authorization } & \text { Total } \\ \text { d. Buildings: } & \text { Original } & 5 & 11 & 16 \\ & \text { 1st Revision } & 31 & 43(20 \mathrm{AFH}) & 74 \\ & \text { Final } & 34 & 41(20 \mathrm{AFH}) & 75\end{array}$

16

74

75

e. Increase in buildings over 1st revised scope.

Building Nos. 119D, 119E, and 122

f. Decrease in buildings over 1st revised scope due to work already accomplished.

Building Nos. 146 and 225

g. Primary Quantities:

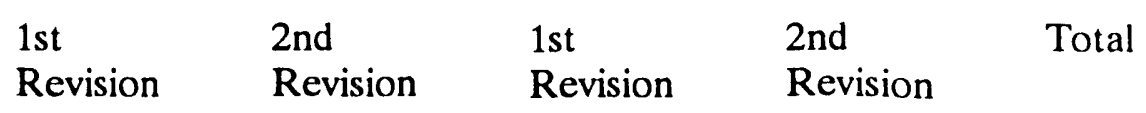

Pumps (ea)

Mixing valve (ea)

Radiator (ea)

Thermostat valves (ea)

DHW

Generator (ea)

Manifolds (ea)

Long Distance Pipes(lf)

EMCS Substations (ea)

EMCS Thermostats (ea)

$\begin{array}{cc}31 & 126 \\ 26 & 80 \\ 213 & 428 \\ 213 & 428 \\ & \\ 24 & 25 \\ 10 & 42 \\ 1,410 & 2,791 \\ 0 & 6 \\ 0 & 92\end{array}$

126

80

28

32

18

243

243

$\begin{array}{rr}80 & 206 \\ 93 & 173 \\ 277 & 705 \\ 277 & 705\end{array}$

25

42

92

56
80
3,740
6
363

h. Rationale for Increase:

The MILCOM, in developing their original and revised estimates, anticipated a rather simple connection procedure. The German design agency determined this approach could not be used and proceeded to design in accordance with EMC'; and German construction standards. Due to a lack of project coordination among the design agent, EUD, and the Goeppingen MILCOM, the changes were not known until the prefinal design was reviewed. The time of the development of the final cost estimate is debatable depending on which individual is queried.

i. Bids have been evaluated and a similar cost increase is not expected to occur for project S-GP-0141-80 at Hardt Kaserne in Schwaebisch Gmuend. 


\section{INTERNAL DISTRIBUTION}

1. M. A. Broders

2. R. S. Carlsmith

3. G. E. Courville

4. G. A. Dailey

5. S. J. Dale

6. C. D. Doty

7. W. Fulkerson

8-12. M. B. Gettings

13. P. S. Gillis

14. C. R. Kerley

15. M. A. Kuliasha

16. B. W. McConnell

17. W. R. Mixon

18- 27. S. L. Purucker

28. D. E. Reichle
29. M. W. Rosenthal

30. M. P. Ross

31. R. B. Shelton

32. J. N. Stone

33. A. W. Trivelpiece

34. T. J. Wilbanks

35. Central Research Library

36. Document Reference Section

37. Laboratory Protection Division

38. ORNL Patent Office

39. ORNL Public Relations Office

40-41. Laboratory Records

42. Laboratory Records - RC

\section{EXTERNAL DISTRIBUTION}

43. K. G. Briggs, Jr., Program Manager, European Office, Martin Marietta Energy Systems, Inc., Rathausstrasse 15, D-6906 Leimen, Germany

44. B. G. Buchanan, Computer Science Department, University of Pittsburgh, 206 Mineral Industries Building, Pittsburgh, Pennsylvania 15260

45. D. J. Cannon, Chief Utilities and Energy, HQ, U.S. Army, Europe, AEAEN-FE-U, APO, New York 09403

46. H. F Carlen, Chief of Electronic Technology Branch, U.S. Army Corp of Engineers, HNDED-ME, P.O. Box 1600, Huntsville, AL 35807

47. M. Carr, Assistant for Energy Policy, Office of the Secretary of Defense, DASO(L)EP, Washington, DC 20301-8000

48. F. J. Collins, Department of Energy, CE-141, 5E-066/FORSTAL, 1000 Independence Ave., SW Washington, DC 20585

49-50. Commander, Goeppingen Base Support Battalion, Attn: AETSGPN-DEH, Mr. Farrell, APO AE 09454-0029

51. Commander, Goeppingen Base Support Battalion, Attn: AETSGPN-DEH, Mr. Jacob, APO AE 09454-0029

52. Commander, Stuttgart 6th ASG, Attn: DEH, APO AE 09154

53. J. W. Cooke, DOE-OR

54. R. L. Egli, DOE-OR

55. A. Hirsch, Vice President, Environmental Sciences and Director, Washington Operations, Midwest Research Institute, 5109 Leesburg Pike, Suite 414, Falls Church, Virginia 22041

56. R. O. Hultgren, Deputy Assistant Manager for Energy Research and Development, Department of Energy, Oak Ridge Field Office, Oak Ridge, Tennessec 37831 
57. H. M. Ingram, Director, Udall Center for Studies in Public Policy, The University of Arizona, 803/811 East First Street, Tucson, Arizona 85719

58. R. Karney, U.S. Army Engineering and Housing Support Center, Attn: CEHSE-FUM, Ft. Belvoir, VA 22060-5580

59. C. D. MacCracken, President, Calmac Manufacturing Corporation, 101 West Sheffield Ave., P. O. Box 710, Englewood, New Jersey 07631

60. J. P. Millhone, DAS, Office of Building Technologies, Department of Energy, CE-40, 6A-081/FORSTAL, 1000 Independence Ave., SW Washington, DC 20585

61-70. J. Mitchell, Electronics Engineer, HQ, U.S. Army, Europe, AEAEN-FE-U, APO, New York 09403

71. R. Nader, P. O. Box 19367, Washington, DC 20036

72. J. W. Nehls, Sr., DOE-OR

73-82. Office of Scientific and Technical Information, P. O. Box 62, Oak Ridge, Tennessee 37831

83. J. B. Shrago, Director, Office of Technology Transfer, 405 Kirkland Hall, Vanderbilt University, Nashville, Tennessee 37240

84. R. Q. Spradlen, DOE-OR

85. M. Williams, Professor, Department of Economics, Northern Illinois University, DeKalb, Illinois 60115 

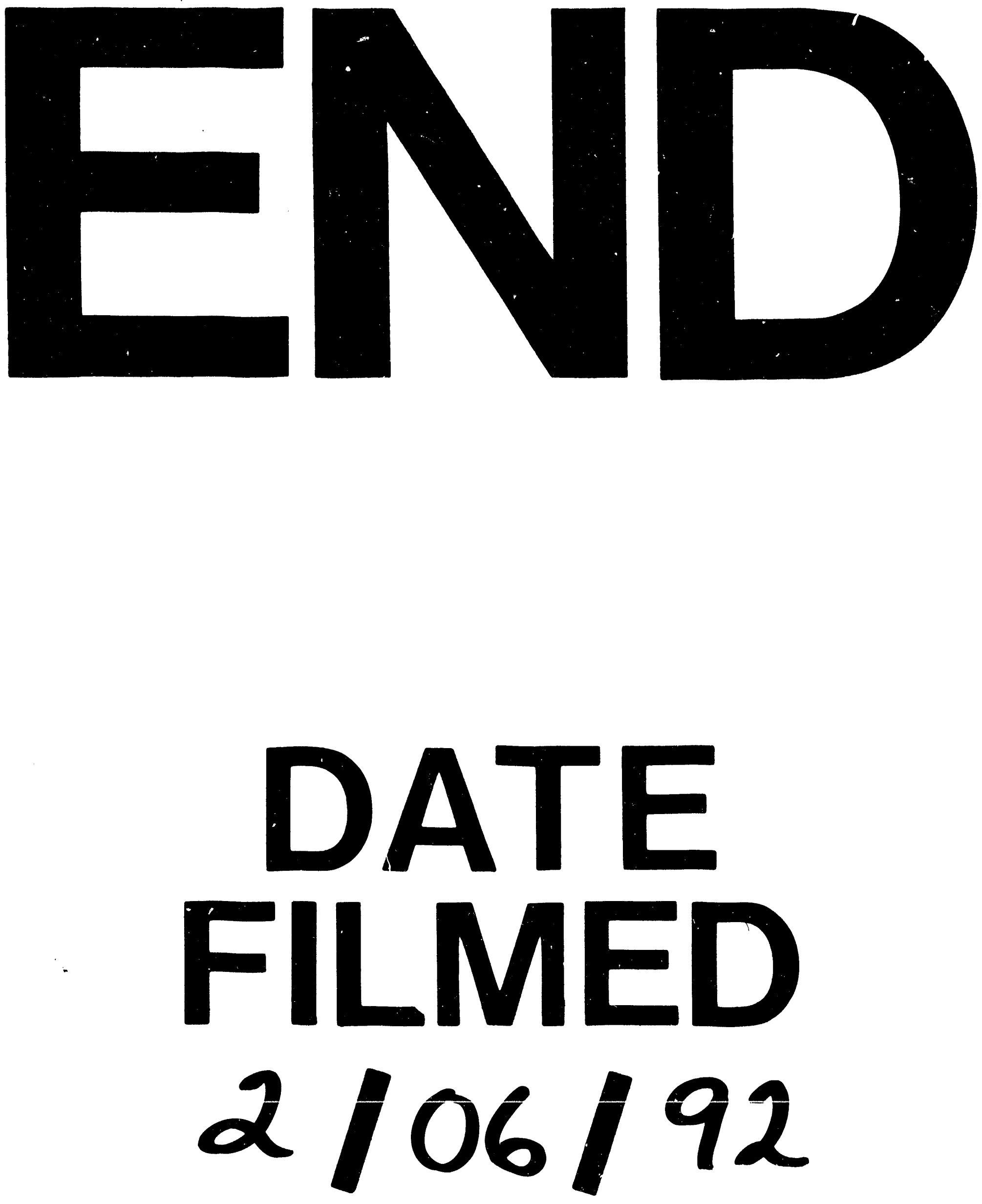

1 